\title{
Functional food science and gastrointestinal physiology and function
}

\author{
S. Salminen ${ }^{1}$, C. Bouley ${ }^{2}$, M.-C. Boutron-Ruault ${ }^{3}$, J. H. Cummings ${ }^{4 *}$, A. Franck ${ }^{5}$, G. R. Gibson ${ }^{6}$, \\ E. Isolauri ${ }^{7}$, M.-C. Moreau ${ }^{8}$, M. Roberfroid ${ }^{9}$ and I. Rowland ${ }^{10}$ \\ ${ }^{1}$ Department of Biochemistry and Food Chemistry, University of Turku, SF-20500 Turku, Finland \\ ${ }^{2}$ Groupe Danone, 15, Av. Galilée, F-92350 Le Plessis-Robinson, France \\ ${ }^{3}$ U290 INSERM, Hôpital St Lazare, 107, rue du Faubourg Saint-Denis, F-75010 Paris, France \\ ${ }^{4}$ Dunn Clinical Nutrition Centre, Hills Road, Cambridge CB2 2DH, UK \\ ${ }^{5}$ Raffinerie Tirlemontoise - ORAFTI, Aandorenstraat 1, B-3300 Tienen, Belgium \\ ${ }^{6}$ Institute of Food Research, Reading Laboratory, Earley Gate, Reading RG6 6BZ, UK \\ ${ }^{7}$ University of Tampere Medical School, PO Box 607, SF-33101 Tampere, Finland \\ ${ }^{8}$ INRA - Unité d'Ecologie et de Physiologie du Système Digestif, Bâtiment 440 R-2, \\ Domaine de Vilvert, F-78352 Jouy-en-Josas Cedex, France \\ ${ }^{9}$ UCL, Ecole de Pharmacie, Tour Van Helmont, Avenue E. Mounier, 73, B-1200 Brussels, Belgium \\ ${ }^{10}$ University of Ulster, Coleraine BT52 ISA, UK
}

1. Introduction

2. Intestinal microflora: physiology and functions

2.1. The normal flora

2.2. Fermentation and short-chain fatty acids $\quad$ S149

2.2.1. Physiology and health

2.2.2. Acetate

2.2.3. Propionate

2.2.4. Butyrate

2.3. Interactions between the intestinal microflora and epithelial cells

2.4. The concept of healthy microflora

3. The gastrointestinal immune system

3.1. Gut-associated lymphoid tissue (GALT)

3.2. The structure of GALT and cell distribution

3.3. Immunophysiological regulation

3.4. Regulation of antigen transfer

3.5. Interactions between the intestinal microflora and the GALT

4. Mucosal cell proliferation and differentiation

4.1. Cell proliferation

4.2. Differentiation

4.3. Apoptosis

4.4. Mucosal enzymes

5. Gastrointestinal function and disease

5.1. Gastrointestinal infections

5.2. Normal bowel habit

5.3. Constipation

5.4. Irritable bowel syndrome (IBS)

5.5. Inflammatory bowel disease

5.5.1. Crohn's disease

5.5.2. Ulcerative colitis

5.6. Food allergy

\section{Contents}

\begin{tabular}{|c|c|c|c|}
\hline S148 & 5.7. & Colorectal cancer & S156 \\
\hline S148 & 6. Metl & lodology & S156 \\
\hline S148 & 6.1. & Human intestinal microflora & $\$ 156$ \\
\hline S149 & 6.2. & Functional analysis of the gut microflora & S157 \\
\hline S149 & & 6.2.1. Bacterial enzymes & S158 \\
\hline S149 & & 6.2.2. Bacterial metabolites in faeces & $\mathrm{S} 158$ \\
\hline S149 & & 6.2.3. Assessment of cytotoxicity, genotoxicity and & \\
\hline S149 & & mutagenicity of faeces & $\mathrm{S} 158$ \\
\hline S151 & & $\begin{array}{l}\text { 6.2.4. Susceptibility of functional markers to } \\
\text { dietary change }\end{array}$ & $\mathrm{S} 158$ \\
\hline S151 & 6.3. & Digestibility and bioavailability of foods & $\mathrm{S} 158$ \\
\hline S152 & 6.4 & Large-bowel function & S158 \\
\hline S152 & 6.5. & Gut-associated lymphoid tissue & S159 \\
\hline S152 & 6.6. & Epithelial cell proliferation and colon & \\
\hline S152 & & carcinogenesis & $\mathrm{S} 160$ \\
\hline S153 & & $\begin{array}{l}\text { 6.6.1. Biological markers for colorectal } \\
\text { carcinogenesis }\end{array}$ & S160 \\
\hline S153 & & 6.6.2. Cell proliferation & $\mathrm{S} 160$ \\
\hline S154 & & 6.6.3. Differentiation & $\mathrm{S} 161$ \\
\hline S154 & & 6.6.4. Apoptosis & S161 \\
\hline S154 & & 6.6.5. Products used in experimental & \\
\hline S154 & & carcinogenesis & S161 \\
\hline S154 & & 6.6.6. Types of lesion & S161 \\
\hline S154 & & 6.6.7. Transgenic mouse models for colon cancer & \\
\hline S154 & & studies & S161 \\
\hline S155 & & 6.6.8. Limits of experimental models & S162 \\
\hline S155 & 7. Hum & an studies on the effects of food and food & \\
\hline S155 & $\operatorname{com}$ & onents & S16 \\
\hline S155 & 7.1. & Prebiotics & S162 \\
\hline S155 & 7.2 . & Probiotics & S163 \\
\hline S156 & & 7.2.1. Alleviation of lactose intolerance symptoms & S163 \\
\hline S156 & & 7.2.2. Immune enhancement & S16 \\
\hline
\end{tabular}

Abbreviations: GALT, gut-associated lymphoid tissue; IBS, irritable bowel syndrome; Ig, immunoglobulin; ILSI, International Life Sciences Institute; IQ, 2 amino-3-methyl-7H-imidazo[4,5-f] ]quinoline; MTT, 3-[4,5-dimethyl-thiazol-2-yl]-2,5-diphenyltetrazolium bromide; 7-OHIQ, 7-hydroxy-2-amino-3,6dihydro-3-methyl-7H-imidazo[4,5-f] quinoline-7-one; rRNA, ribosomal RNA; SCFA, short-chain fatty acids.

*Corresponding author: Dr J. H. Cummings, fax +44(0)1223 413763, email john.cummings@mrc-dunn.cam.ac.uk 
7.2.3. Acute gastroenteritis

7.2.4. Faecal mutagenicity and enzymes

7.3. Diet and colon cancer

7.3.1. Dietary protective factors

\section{Safety issues}

8.1. Prebiotics

8.2. Probiotics

9. Critical evaluation of present knowledge

9.1. Intestinal microflora

9.2. Mucosal function

9.3. Gastrointestinal physiology

9.4. Methodology
9.5. Human studies on health benefits $\quad$ S165

9.5.1. Prebiotics $\quad$ S165

9.5.2. Probiotics $\$ 165$

9.5.3. Diet and colon cancer $\quad$ S165

9.6. Safety $\$ 165$

10. Recommendations for future research priorities $\quad S 165$

10.1. Intestinal microflora

10.2. Short-chain fatty acids and intestinal microflora $\mathrm{S} 166$

10.3. Diet and cancer

10.4. Immune system $\quad \mathrm{S166}$

10.5. Gut mucosa $\quad \mathrm{S} 166$

\begin{abstract}
The gut is an obvious target for the development of functional foods, acting as it does as the interface between diet and the metabolic events which sustain life. The key processes in digestive physiology which can be regulated by modifying diet are satiety, the rate and extent of macronutrient breakdown and absorption from the small bowel, sterol metabolism, the colonic microflora, fermentation, mucosal function and bowel habit, and the gut immune system. The intestinal microflora is the main focus of many current functional foods. Probiotics are foods which contain live bacteria which are beneficial to health whilst prebiotics, such as certain nondigestible oligosaccharides which selectively stimulate the growth of bifidobacteria in the colon, are already on the market. Their claimed benefits are to alleviate lactose maldigestion, increase resistance to invasion by pathogenic species of bacteria in the gut, stimulate the immune system and possibly protect against cancer. There are very few reports of well-designed human intervention studies with prebiotics as yet. Certain probiotic species have been shown to shorten the duration of rotavirus diarrhoea in children but much more work is needed on the mechanism of immunomodulation and of competitive exclusion and microflora modification. The development of functional foods for the gut is in its infancy and will be successful only if more fundamental research is done on digestive physiology, the gut microflora, immune system and mucosal function.
\end{abstract}

\title{
Gastrointestinal function: Microflora: Immune system
}

\section{Introduction}

One of the most promising areas for the development of functional foods lies in modification of the activity of the gastrointestinal tract by use of probiotics, prebiotics and synbiotics. To understand the potential value of these functional foods and to be able to develop new approaches it is necessary to study the normal human intestinal flora, fermentation, the gut immune system, mucosal function and the principal gut-related diseases.

\section{Intestinal microflora: physiology and functions}

\subsection{The normal flora (Gibson \& Macfarlane, 1995)}

Bacterial numbers and composition vary considerably along the human gastrointestinal tract. The total bacterial count in gastric contents is usually below $10^{3} / \mathrm{g}$, with numbers being kept low due to the acid lumen $\mathrm{pH}$. In the small intestine, numbers range from approximately $10^{4} / \mathrm{ml}$ contents to about $10^{6}-10^{7} / \mathrm{ml}$ at the ileocaecal region. The main factors limiting growth in the small bowel are the rapid transit of contents and secretion of bile and pancreatic juice.

The human large intestine is an intensely populated microbial ecosystem. Several hundred species of bacteria are usually present, with typical numbers of about $10^{11}-10^{12} / \mathrm{g}$. The majority of these bacteria are strict anaerobes.
Table 1 lists bacteria commonly isolated from the human colon. Bacterial counts of individual species range over several orders of magnitude, and the nutrition and metabolic products of different bacterial groups vary considerably. Most bacteria growing in the colon are non-sporing anaerobes and include members of the genera Bacteroides, Bifidobacterium and Eubacterium among many others. Clostridia are also represented, although they are outnumbered by the non-sporing anaerobes, as are facultative anaerobes such as streptococci and enterobacteria. Quantitatively, the most important genera of intestinal bacteria in animals and man are the bacteroides and bifidobacteria, which can account for $30 \%$ and $25 \%$ of the total anaerobic counts respectively. The Gram-negative Bacteroides group (e.g. Bacteroides ovatus, Bacteroides fragilis, Bacteroides thetaiotaomicron) are thought to be numerically predominant. The genus contains both proteolytic and saccharolytic species. Amongst the Gram-positive, non-sporing rods, several genera are numerically significant. Obligate anaerobes include eubacteria and bifidobacteria, such as Bifidobacterium bifidum and Bifidobacterium infantis, which are prominent in the faeces of breast-fed infants. The genus Lactobacillus contains many species that occur in the gut of most warm-blooded animals. Although numerically important in the alimentary tract, their ecological significance has not been conclusively determined. 
Table 1. Bacteria, their substrates and products in the human large intestine (From Macfarlane et al. 1995)

\begin{tabular}{|c|c|c|c|c|c|}
\hline \multirow[b]{2}{*}{ Bacteria } & \multirow[b]{2}{*}{ Description } & \multicolumn{2}{|c|}{$\begin{array}{l}\text { Concentration } \\
\left(\log _{10} / g \text { dry wt faeces) }\right.\end{array}$} & \multirow[b]{2}{*}{ Substrate } & \multirow{2}{*}{$\begin{array}{l}\text { Fermentation } \\
\text { products }\end{array}$} \\
\hline & & Mean & Range & & \\
\hline Bacteroides & $\mathrm{G}-$ rods & $11 \cdot 3$ & $9.2-13.5$ & Saccharolytic & $\bar{A}, P, S$ \\
\hline Eubacteria & $\mathrm{G}+$ rods & $10 \cdot 7$ & $5 \cdot 0-13 \cdot 3$ & $\begin{array}{l}\text { Saccharolytic, some amino acid fermenting } \\
\text { species }\end{array}$ & $A, B, L$ \\
\hline Bifidobacteria & $\mathrm{G}+$ rods & $10 \cdot 2$ & $4.9-13 \cdot 4$ & Saccharolytic & $A, L, f, e$ \\
\hline Clostridia & $\mathrm{G}+$ rods & $9 \cdot 8$ & $3 \cdot 3-13 \cdot 1$ & $\begin{array}{l}\text { Saccharolytic and amino acid fermenting } \\
\text { species }\end{array}$ & $A, P, B, L, e$ \\
\hline Lactobacilli & $\mathrm{G}+$ rods & 9.6 & $3.6-12.5$ & Saccharolytic & L \\
\hline Ruminococci & $\mathrm{G}+\operatorname{cocci}$ & $10 \cdot 2$ & $4 \cdot 6-12 \cdot 8$ & Saccharolytic & A \\
\hline Peptostreptococci & $\mathrm{G}+\operatorname{cocci}$ & $10 \cdot 1$ & $3.8-12 \cdot 6$ & As for the clostridia & $A, L$ \\
\hline Peptococci & $\mathrm{G}+\operatorname{cocci}$ & $10 \cdot 0$ & $5 \cdot 1-12 \cdot 9$ & Amino acid fermenters & $A, B, L$ \\
\hline Methanobrevibacter & $\mathrm{G}+$ cocco bacilli & $8 \cdot 8$ & $7 \cdot 0-10.5$ & Chemolithotrophic & $\mathrm{CH}_{4}$ \\
\hline Desulfovibrios & G- rods & 8.4 & $5 \cdot 2-10 \cdot 9$ & Various & A \\
\hline Propionibacteria & $\mathrm{G}+$ rods & 9.4 & $4 \cdot 3-12 \cdot 0$ & Saccharolytic, lactate fermenting & $A, P$ \\
\hline Actinomyces & $\mathrm{G}+$ rods & $9 \cdot 2$ & $5.7-11 \cdot 1$ & Saccharolytic & A, L, S \\
\hline Streptococci & $\mathrm{G}+\operatorname{cocci}$ & 8.9 & $3 \cdot 9-12 \cdot 9$ & Carbohydrate and amino acid fermenting & L, A \\
\hline Fusobacteria & G- rods & 8.4 & $5 \cdot 1-11 \cdot 0$ & $\begin{array}{l}\text { Amino acid fermentation, carbohydrate } \\
\text { also assimilated }\end{array}$ & $B, A, L$ \\
\hline Escherichia & $\mathbf{G}$ - rods & $8 \cdot 6$ & $3 \cdot 9-12 \cdot 3$ & As for streptococci & Mixed acids \\
\hline
\end{tabular}

$G+$, Gram-positive; $G-$, Gram-negative; A, acetate; P, propionate; $B$, butyrate; L, lactate; $S$, succinate; $f$, formate; e, ethanol.

Several types of spore-forming rods and cocci are also inhabitants of the gut. The genus Clostridium is probably the most common: $C$. perfringens, $C$. bifermentans and C. tetani are regularly isolated, albeit in relatively low numbers, and are of significance in human and veterinary medicine. Facultative and obligately anaerobic Gram-positive cocci are also numerically important. The strict anaerobes include Peptostreptococcus, Ruminoccus, Megasphaera elsdenii and Sarcina ventriculi. The facultatively anaerobic streptococci are well represented by many species from Lancefield group D, including S. faecalis, S. bovis and S. equinus, and some from group $\mathrm{K}$, such as $S$. salivarius, which is usually associated with the mouth. Gram-negative anaerobic cocci include Veillonella and Acidaminococcus.

Although not numerous, the Gram-negative facultative anaerobic rods include a number of important pathogens. For example, members of the Enterobacteriaceae, particularly Escherichia coli, are usually thought of as characteristic intestinal bacteria.

The large-gut microflora is acquired at birth. Initially, facultatively anaerobic strains dominate. Thereafter, differences exist in the species composition that develops and this is largely controlled by the type of diet. The faecal flora of breast-fed infants is dominated by bifidobacteria. In contrast, formula-fed infants have a more complex microbiota with bifidobacteria, bacteroides, clostridia and streptococci all being prevalent. After weaning, a pattern that resembles the adult flora becomes established (Ducluzeau, 1993).

The principal role of the intestinal microflora is to salvage energy from carbohydrates not digested in the upper gut, through fermentation. The major substrates for fermentation are dietary carbohydrates that have escaped digestion in the upper gastrointestinal tract. These include starch that enters the colon (resistant starch), as well as NSP, e.g. cellulose, hemicelluloses, pectins and gums. Other carbohydrate sources available for fermentation are non-digestible oligosaccharides, various sugars and sugar alcohols (Cummings $e t$ al. 1997). In addition, proteins and amino acids can be effective as growth substrates for colonic bacteria. These include elastin, collagen and albumin, as well as bacterial protein released following cell lysis. Pancreatic enzymes represent a source of N. Bacterial secretions, lysis products, sloughed epithelial cells and mucins may also make a contribution as fermentation substrates. Total substrate availability in the human adult colon is $20-60 \mathrm{~g}$ carbohydrate and $5-20 \mathrm{~g}$ protein/d (Cummings \& Englyst, 1987; Cummings et al. 1989).

Significant regional differences occur in bacterial activity in the colon. The right (proximal) colon is characterized by a high substrate availability (due to dietary input), low $\mathrm{pH}$ (from acids produced in fermentation) and rapid transit. The left, or distal, colon has a lower concentration of available substrate, the $\mathrm{pH}$ is approximately neutral and bacteria grow more slowly. The proximal region tends to be a more saccharolytic environment than the distal gut, the latter having higher bacterial proteolysis.

In addition to its role in fermentation the large-intestinal microflora contributes towards health in a number of other ways. The development of the intestinal microflora provides the basis for a barrier that prevents pathogenic bacteria from invading the gastrointestinal tract. The composition of the intestinal microflora together with the gut immune system allows resident bacteria to exert a protective function. In addition gut bacteria are involved in vitamin synthesis (especially vitamins $\mathbf{B}$ and $\mathrm{K}$ ) and in the metabolism of xenobiotics. Thus, modification of the flora by dietary means offers one of the most effective opportunities for development of functional foods.

\subsection{Fermentation and short-chain fatty acids (Binder et al. 1994; Cummings, 1995; Cummings et al. 1995)}

Through fermentation, bacterial growth is stimulated (biomass), and short-chain fatty acids (SCFA) and the gases $\mathrm{H}_{2}$, $\mathrm{CO}_{2}$ and $\mathrm{CH}_{4}$ are produced. 
SCFA are the major end-products of bacterial fermentative reactions in the colon and are the principal anions in the hindgut of man and all other mammals. The SCFA are acetate, propionate and butyrate but other significant endproducts of carbohydrate fermentation include lactate, ethanol, succinate, formate, valerate and caproate (Table 1). Branched-chain fatty acids such as isobutyrate, 2-methylbutyrate and isovalerate may be formed from the fermentation of amino acids that originate in proteolysis. The other end-products from bacterial metabolism of proteins include $\mathrm{NH}_{3}$, phenols, indoles and amines, some of which have toxic properties (Macfarlane \& Macfarlane, 1995).

The amount of SCFA, which is usually in excess of $100 \mathrm{mmol} / \mathrm{kg}$ contents, and the molar ratios of the three principal acids produced by fermentation, vary substantially, depending on the substrate. This has been studied extensively in vitro using single-chamber chemostat models of the gut inoculated with intestinal micro-organisms. Yields vary from $40-60 \%$ (g SCFA/100 g substrate utilized), with molar ratios of acetate from 60-80, propionate 14-22 and butyrate 8-23 (Cummings, 1995). Whilst acetate is produced in all fermentation systems in vitro, it is the major product of pectin breakdown. Similarly, the highest molar ratios of propionate are seen characteristically with arabinogalactan and guar gum as substrate. Amounts of butyrate vary perhaps more than any other according to substrate but the polysaccharide that is associated with the highest relative amounts is starch. In animal studies, wheat bran seems to give rise to high concentrations of SCFA in the gut, despite the fact that it is relatively poorly fermented, especially in human subjects (Cheng et al. 1987; McIntyre et al. 1991). Studies in human subjects to determine amounts of SCFA in the gut are difficult, but evidence suggests that caecal concentrations of SCFA are approximately double those in the recto-sigmoid area (Cummings et al. 1987).

The amount of SCFA produced in human subjects is very difficult to determine. Studies of arterio-venous differences across the gut indicate that $300-500 \mathrm{mmol}$ are produced each day, whilst in individual cases this may reach 1-2 mol. Few dynamic studies have been carried out in man because of problems accessing the portal vein and differential metabolism of SCFA by individual tissues. The situation is complicated by endogenous production of acetate by the liver. Future stable-isotope studies may give more information in this area.

SCFA production in the large intestine can be observed qualitatively by measuring levels in blood. However, only acetate appears in significant amounts in peripheral blood, although this responds in both time and amount to substrate fermentation in the large intestine (Pomare et al. 1985; Lifschitz et al. 1995).

2.2.1. Physiology and health. All SCFA are rapidly absorbed from the hindgut and stimulate salt and water absorption. They are then metabolized principally by the gut epithelium, liver and muscle, with virtually none appearing in urine and only small amounts in faeces.

One of the most important properties of SCFA is their trophic effect on the intestinal epithelium. All three major SCFA are trophic when infused into the large intestine, although butyrate seems to be the most effective and propionate the least. What is perhaps more interesting is that infusion of SCFA into the hindgut leads to trophic effects in the small intestine (Sakata, 1987; Frankel et al. 1994) although the mechanisms for this are not fully determined. These trophic properties of SCFA have important implications, particularly for patients receiving enteral or parenteral nutrition, and in maintaining the mucosal defence barrier against invading organisms.

2.2.2. Acetate. Acetate is the principal SCFA in the gut. It is taken up by the epithelium, appears in portal blood and eventually passes through the liver to peripheral tissues where it is metabolized by muscle. In animal studies, the liver secretes free acetate when levels in portal blood fall below a critical level. Uptake and utilization of acetate by many tissues has been shown and is the principal route whereby the body obtains energy from carbohydrates not digested and absorbed in the small intestine. Current evidence suggests that the energy value of fermented carbohydrate is $6.3-8.4 \mathrm{~kJ} / \mathrm{g}(1.5-2 \mathrm{kcal} / \mathrm{g}$ ) (Livesey, 1990; Roberfroid et al. 1993).

2.2.3. Propionate. In ruminant species, propionate is a major glucose precursor but this is not an important role in hindgut fermenting species such as man. Propionate is largely cleared by the liver and has not been shown consistently to have significant effects on carbohydrate metabolism in human subjects. In vitro, propionate inhibits uptake of acetate into the cholesterol synthesis pathway, and in both rats and pigs propionate supplementation of the diet reduces cholesterol levels in blood. In human feeding studies of propionate only one out of three currently reported shows any change in blood cholesterol levels (Venter et al. 1989; Todesco et al. 1991; Stephen, 1994).

2.2.4. Butyrate. Butyrate is the most interesting of the SCFA, since in addition to its trophic effect on the mucosa it is an important energy source for the colonic epithelium and regulates cell growth and differentiation. Butyrate is almost entirely cleared by the colonic epithelium and is the principal energy source for the epithelial cells (Bugaut \& Bentejac, 1993; Cummings, 1995). A defect in butyrate metabolism has been identified in ulcerative colitis patients and may be induced by $\mathrm{S}$ compounds generated in the largebowel lumen (Roediger et al. 1993; Pitcher \& Cummings, 1995).

The effect of butyrate on cell growth and differentiation is of great importance and has been the subject of a number of studies (Boffa et al. 1992; McIntyre et al. 1993). Butyrate brings about a concentration-dependent slowing of the rate of transformed cell growth and promotes expression of differentiation markers in vitro, thus leading to reversion of cells from a neoplastic to a non-neoplastic phenotype (Kim et al. 1980, 1994; Whitehead et al. 1986; Gibson et al. 1992). In vitro studies with colonocytes suggest an interaction between long-chain fatty acids, which result in decreased viability and differentiation of the cells, and butyrate, which has the opposite effect (Awad et al. 1991). In carcinogen-induced animal models of largebowel cancer, however, butyrate, either from fermentable carbohydrate sources such as resistant starch or purified NSP such as pectin, leads to increased cell turnover and in some studies increased tumour formation (Sakamoto et al. 1996; Young et al. 1996). The proliferative effects of 
butyrate are probably not of pathological significance. Butyrate increases the proliferative index at the bottom of the crypt and thereby has a trophic effect on the mucosa. It does not, however, increase the proliferative index of the surface of the crypt (type II abnormality), which is closely connected with risk of colorectal cancer. Moreover, the relevance of these models to human carcinogenesis is doubtful for a number of reasons (see section 6.6). The expression of several genes is affected by butyrate and butyrate response factors have been identified in the upstream element of certain genes (Kim et al. 1994).

\subsection{Interactions between the intestinal microflora and epithelial cells}

Although attachment to the epithelium is thought to be an important factor whereby bacteria colonize the gut, the mechanisms that allow certain species to maintain themselves in specific locations in the intestinal tract are largely unknown. An interesting new observation is that the intestinal microflora can influence expression of epithelial glycoconjugates, which may serve as receptors for attachment of (pathogenic) micro-organisms. Recent papers by Bry et al. (1996) and Umesaki et al. (1995, 1997) report that host epithelial cells in the small intestine express fucosylated glycoconjugates in response to the presence of specific, strictly anaerobic bacteria ( $B$. thetaiotaomicron and a segmented filamentous bacterium SIF13). Attachment of some pathogenic micro-organisms is decreased by the mutually beneficial crosstalk between the indigenous microflora and the host (Umesaki, 1989). The observation that one species can induce epithelial surface structures which influence attachment of other bacteria has significance for the use of $\mathrm{CaCo}-2$ cell lines or gnotobiotic animals as model systems to study adherence or infectious diseases as well as for strategies to prevent and to treat gastrointestinal diseases. Thus, adhesion of bacteria to mucosal cell lines is important, but their mucus-adhering and degrading properties also need to be addressed.

\subsection{The concept of healthy microflora}

It is a long-held belief, originating probably with Metchnikoff at the turn of the century, that some gut bacteria are

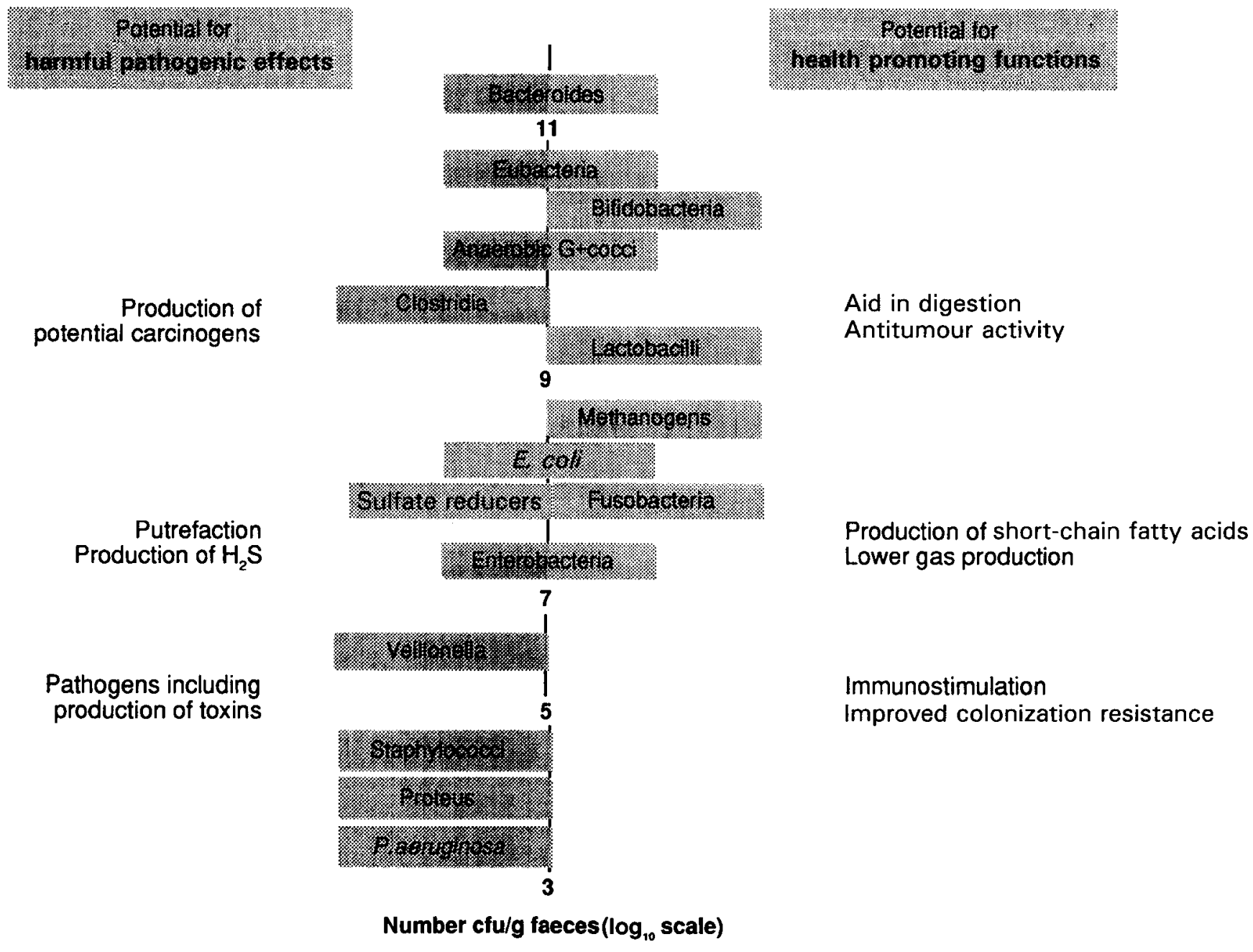

Fig. 1. Generalized scheme of predominant groups of colonic bacteria, indicating how the genera may exhibit potentially harmful and beneficial functions. G+, Gram positive; cfu, colony-forming units. 
beneficial to health, whilst others may be harmful (Fig. 1). That bacteria in the gut can be harmful through production of toxins causing diarrhoea, mucosal invasion and activation of carcinogens is self-evident. Such bacteria are thought to include the Clostridia, sulfate reducers and amino acid-fermenting species.

Potentially health-giving bacteria are thought to include principally the bifidobacteria and lactobacilli. These two genera do not include any significant pathogenic species and their dominance in the faeces of breast-fed babies is thought to provide protection against infection. In adults they may be the principal species responsible for barrier function and for stimulating healthy immune function. In addition, bacteria act in symbiosis with the host through fermentation.

However, the colonic microflora is a complex interactive community of organisms and its functions are a consequence of the combined activities of the microbial components. Thus manipulation of the human intestinal flora offers the potential to improve health through a variety of mechanisms.

\section{The gastrointestinal immune system}

\subsection{Gut-associated lymphoid tissue (GALT) (Brandtzaeg et al. 1989)}

The first, and in normal individuals only, contact that ingested bacteria, including probiotics, have with the immune system is with the GALT. The human intestine represents the largest mass of lymphoid tissue in the body, containing over $10^{6}$ lymphocytes/g tissue. In addition, about $60 \%$ of the total immunoglobulin (Ig; several grams) produced daily is secreted into the gastrointestinal tract. GALT is part of the mucosal immune system (i.e. gastrointestinal tract, respiratory tract, oral cavity, urogenital tract and mammary glands) and has unique cell types and mechanisms of immunity. The special nature of intestinal immunity has evolved under constant exposure to environmental antigens, whilst requiring an effective response to an invading pathogen despite the presence of dietary antigens. The difference between immune responses to dietary proteins and antigens of colonizing bacteria may play a role in the prevention of hypersensitivity reactions to food proteins.

\subsection{The structure of GALT and cell distribution}

Intestinal immune cells are organized in different compartments: aggregated in follicles and the Peyer's patches; distributed within the mucosa as diffuse lymphocyte populations; and in the epithelium (reviewed by McKay \& Perdue, 1993). The GALT T-lymphocytes are not homogeneous. These are classified as CD4+ helper/inducer cells and CD8+ suppressor/cytotoxic cells, generating different cytokine profiles with distinct yet unproven functions (reviewed by Brandtzaeg et al. 1989; Brandtzaeg, 1995). The majority of the intra-epithelial T-cells have a suppressor/cytotoxic phenotype, contrasting with the lamina propria cells, which show mainly a helper/inducer phenotype. The lamina propria is also endowed with lymphocytes belonging to the B-cell lineage. These are mainly memory cells and plasmocytes, where $70-90 \%$ of them are IgA-producing cells.

The epithelial layer of the small-intestinal mucosa is arranged in folds, consisting of villi and crypts, which increase the absorptive surface area. The epithelium consists of a single layer of absorptive columnar epithelial cells, goblet cells and intra-epithelial lymphocytes. The intraepithelial lymphocytes are a heterogeneous population of cells. In the mouse, the primary intra-epithelial lymphocytes are $\mathrm{CD} 3+, \mathrm{CD} 8+, \mathrm{T}$-cells with a $\gamma / \delta$-T-cell receptor (T-cell receptor 1) and in man CD8 T-cells expressing an $\alpha / \beta$-cell receptor (T-cell receptor 2). The proportion of $\mathrm{T}$-cell receptor 1 cells in the epithelium is greater than in peripheral blood. The $\gamma / \delta$-T-cell receptor cells are thought to mature in the epithelium rather than in the thymus, thus their development might be more susceptible to environmental exposures. Intra-epithelial lymphocytes are known to mediate both non-major-histocompatibility-complexrestricted and major-histocompatibility-complex-restricted cytotoxicity, and regulate neighbouring immune and epithelial cells by secreting cytokines.

The epithelium is surrounded by the lamina propria, which comprises lymphoid organs such as reticular tissue and which contains plasma cells, T-helper cells, granulocytes and mast cells. The lamina propria is surrounded by smooth-muscle tissue. Along the small intestine are Peyer's patches, which are organized lymphoid follicle aggregates. The Peyer's patches are more accessible to micro-organisms than other epithelial surfaces of the gut, because they have reduced numbers of the mucus-secreting goblet cells. In addition, the epithelial layer of the Peyer's patches contains specialized transport cells called M-cells, which lack microvilli and are able to phagocytose both soluble antigens and micro-organisms.

\subsection{Immunophysiological regulation (Brandtzaeg, 1995)}

Different components of the mucosal immune system act to focus a specific response against offending antigens. The first line in this defence, immune exclusion involving $\operatorname{Ig} \mathrm{A}$ antibodies, is non-inflammatory (Brandtzaeg, 1995). The best-characterized component of the mucosal immune defence is the secretory IgA system (Brandtzaeg, 1995). IgA antibody production is abundant at mucosal surfaces. IgG-, IgM- and IgE-secreting cells function also, but at a significantly lower frequency in GALT. In contrast to IgA in serum, secretory IgA is present in dimeric or polymeric form in the gut. The predominance of $\operatorname{IgA}$ in the mucosal immune system results from IgA-selective T-cell regulation in GALT, particularly in the Peyer's patches, where specific immune responses are generated (Biewenga et al. 1993). After being synthesized by IgA precursor cells, polymeric IgA is transported to the mucosal surface by epithelial transcytosis mediated by the polymeric immunoglobulin receptor, the secretory component. Secretory IgA is resistant to intraluminal proteolysis, and does not activate complement or inflammatory responses, which makes IgA ideal for protecting the mucosal surfaces. Hence, the main function of secretory antibodies is, in cooperation with nonimmunological defence mechanisms (Sanderson \& Walker, 1993), to mediate immune exclusion of foreign antigens by 
preventing epithelial adherence and penetration of invasive pathogenic micro-organisms, neutralizing toxins and viral multiplication.

Although GALT is mainly involved in specific immune protection of the gut, there is evidence for a "common mucosal immune system': an immune response initiated in GALT can affect immune responses at other mucosal surfaces (Brandtzaeg, 1995). The lymphocytes activated within Peyer's patches disseminate via mesenteric lymph nodes, thoracic duct and the bloodstream back to the lamina propria, and traffic between other secretory tissues, including the respiratory tract and the lachrymal, salivary and mammary glands.

There are differences between the upper and lower parts of the human GALT in isotype distribution of immunoglobulin-producing cells. Two IgA subclasses are available $\left(\operatorname{Ig} \mathrm{A}_{1}\right.$ and $\left.\operatorname{Ig} \mathrm{A}_{2}\right) . \operatorname{Ig} \mathrm{A}_{1}$ immunocytes predominate in the small-intestinal mucosa, while $\operatorname{Ig} \mathrm{A}_{2}$ are most frequent in normal colonic mucosa. $\operatorname{IgA}_{2}$ in the colon is resistant to most bacterial proteases that cleave $\operatorname{Ig} \mathrm{A}_{1}$ (Brandtzaeg, 1995).

Immune elimination is directed towards removal of foreign antigens that have penetrated the mucosa. This second line of defence involves antibodies such as IgG and a large number of mediators such as inflammatory cytokines, which are considered to be responsible for the pathophysiology associated with local inflammation (Brandtzaeg, 1995). Immune regulation pertains to the state of specific hyporesponsiveness induced by prior oral administration of antigens, inducing oral tolerance. Consequently, hyporesponsiveness to ubiquitous antigens such as dietary antigens is a hallmark of the intestinal immune system (Weiner et al. 1994). This has been taken to be a combined effect of immune exclusion and suppression of the systemic immune response, but it is still a matter of debate.

\subsection{Regulation of antigen transfer (Isolauri et al. 1993a,b)}

Antigens are proteins foreign to the host. Factors that influence antigenicity include molecular complexity, solubility and concentration. Most antigens are macromolecules in the molecular mass range $10000-70000 \mathrm{Da}$.

Apart from the barrier function, the intestinal mucosa is efficient in assimilating antigens. For this purpose, there are specialized antigen transport mechanisms in the villous epithelium and particularly in the Peyer's patches (Heyman et al. 1982). The manner in which an antigen is transported across the mucosa determines the subsequent immune response (Heyman et al. 1982; Heyman \& Desjeux, 1992; Isolauri et al. 1993a, $b$; Sanderson \& Walker, 1993).

Most antigens are excluded by a well-functioning mucosal barrier but an immunologically important fraction of antigen does bypass it (Heyman et al. 1982; Isolauri et al. $1993 a, b)$. Antigens are absorbed across the epithelial layer by transcytosis, and the main degradative pathway entails lysosomal processing of the antigen. A minor pathway allows the transport of unprocessed antigens. The Peyer's patches are covered by a unique epithelium and antigen transport across this is characterized by rapid uptake and reduced degradation of antigens. In health, paracellular leakage of macromolecules is prevented because intact intercellular tight junctions maintain the barrier to macromolecules. Consequently, in healthy subjects antigen transfer is well controlled and aberrant antigen absorption does not occur.

There is evidence that during the process of absorption across the intestinal mucosa, dietary antigens are altered into a tolerogenic form (Weiner et al. 1994). By interfering with this process intestinal inflammation is an important risk factor for the development of hypersensitive disorders (Fargeas et al. 1995).

\subsection{Interactions between the intestinal microflora and the GALT (Moreau \& Coste, 1993)}

After birth, the intestine is rapidly colonized by bacteria, which probably act as a source of antigens and non-specific immunomodulators. The dual role of the digestive flora on the immune system should be emphasized. Bacteria can be considered as antigens able to elicit specific systemic and local immune responses. Furthermore, they exert a considerable influence on the number and distribution of the GALT cell populations and play an important role in the regulation of immune responses. These data have emerged mainly from animal studies using germ-free and gnotobiotic animal models (see section 6.5). As direct evidence from human subjects is scarce, we can only extrapolate from experimental results obtained in mice. Such studies are important to determine the exact role played by different bacteria present in the digestive flora, with the aim of improving the bacterial equilibrium and allowing the best immune modulation by functional foods. The cellular and molecular events by which the digestive flora modulates the immune system are still poorly understood.

The digestive flora is the major antigenic stimulus responsible for the migratory pathway and maturation of precursor lymphoid cells present in the Peyer's patches. Consequently, it acts on the development and maturation of the IgA plasmocytes. In germ-free mice, IgA-plasmocyte number is decreased tenfold as compared with controls. It has been shown that the sequential establishment of the digestive flora from birth to weaning is responsible for the progressive increase in IgA plasmocyte numbers in the lamina propria of the small intestine in the growing normal mouse. In addition, Gram-negative bacteria such as Escherichia coli and Bacteroides play an important role in this immunologically non-specific effect.

The digestive flora also modulates the specific immune responses at local and systemic levels. It allows the persistence of the systemic unresponsiveness to an antigen, induced by a previous feeding with the same antigen (oral tolerance) (Moreau \& Gaboriau-Routhiau, 1996) and shortens the abrogation of oral tolerance mediated by cholera toxin or E. coli toxin (Gaboriau-Routhiau \& Moreau, 1996), which seems to be a property of Gramnegative bacteria (M. C. Moreau and V. Gaboriau, unpublished results). In another study the presence of the gut flora modulated the intestinal antibody IgA response to rotavirus. Recently, the development of an experimental model of adult germ-free mice infected with a heterologous strain of 
rotavirus allowed investigation of the immunomodulating properties of a strain of Bifidobacterium on the enhancement of the intestinal anti-rotavirus IgA antibody response at cellular and faecal levels (Moreau et al. 1998). At the systemic level, in gnotobiotic mice harbouring a human strain of Bifidobacterium in the intestine or two bacterial strains from yoghurt, Lactobacillus bulgaricus and Streptococcus thermophilus, increases of the specific antibody response in serum and in the phagocytic activity of peritoneal phagocytes were observed respectively (Moreau $e t$ al. 1994).

\section{Mucosal cell proliferation and differentiation (Wright \& Alison, 1984)}

The intestinal mucosa of rodents and other mammals is renewed every 2-3d (Wright \& Alison, 1984). Maintenance of the architecture of the colonic mucosa, in particular of mucosal crypts, is a consequence of the balance amongst a number of factors. Proliferation of stem cells occurs near the base of the crypt. As enterocytes migrate up the crypt they differentiate, mature and become functional in terms of absorption and mucin secretion.

\subsection{Cell proliferation}

This has been well described and a wide variety of methods are available for its estimation in vitro and in vivo in both animals and man (Goodlad \& Wright, 1982; Goodlad, 1989).

\subsection{Differentiation}

Light and electron microscopic examination of human colonic tissue has revealed that stem cells differentiate into a number of cell types, including mucus-secreting cells, columnar cells (thought to have an absorptive and a secretory function) and intestinal endocrine cells. Histochemical studies have shown alterations in secreted glycoproteins between differentiated and undifferentiated regions of the small and large intestine, indicating that a modification of carbohydrate structures accompanies goblet cell differentiation in rat and man (Boland et al. 1992). Furthermore, the mucin of normal colonic mucosa differs markedly from that in cancerous tissue and 'transitional tissue' in the early stages of neoplastic development (Boland et al. 1992). A characteristic of tumours is the presence of poorly differentiated cells: consequently, a dietary treatment that encourages differentiation is potentially beneficial.

\subsection{Apoptosis}

Apoptosis (genetically programmed, autonomous cell death) associated with the removal of damaged cells is considered to be a protective event.

\subsection{Mucosal enzymes (Szarka et al. 1995)}

Phase I, cytochrome P450 enzymes and phase II drugmetabolizing enzymes such as glutathione $S$-transferase $(E C$ 2.5.1.18) and UDP-glucuronosyl transferase (EC
2.4.1.17) are widely distributed in the intestinal mucosa. These enzymes are involved in the biotransformation of mutagens, procarcinogens, steroids and other compounds of exogenous and endogenous origin. Modulation by dietary compounds may result in protection against toxic and carcinogenic damage to tissues (Wattenberg, 1983). In terms of deactivation, the enzyme glutathione $S$-transferase is of particular importance. It is present in many tissues in a variety of forms $(\pi, \mu$ and $\alpha)$ and plays a critical role in protecting tissues from xenobiotics and carcinogens. Glutathione $S$-transferase activity has been found to be lower in individuals at high risk from colon cancer when compared with controls (Szarka et al. 1995).

\section{Gastrointestinal function and disease \\ 5.1. Gastrointestinal infections \\ (Gracey, 1993; Savarino \& Bourgeois, 1993)}

Acute infections of the gut are usually self-limiting, characterized by diarrhoea and often vomiting. The principal pathogens are viruses and bacteria such as Escherichia coli, Campylobacter spp, Vibrio cholerae, Staphylococcus aureus, Bacillus cereus, Clostridium perfringens, Salmonella spp, Shigella spp, Yersinia spp and a number of protozoa, especially Giardia lamblia, Entamoeba histolytica and Cryptosporidium parvum.

Bacteria causing infection are usually classified according to whether they secrete an enterotoxin (toxigenic) or invade the bowel wall (invasive). Toxigenic diarrhoeas include cholera, and both enteropathogenic and enterotoxigenic $E$. coli, whilst the classic invasive organisms are Shigella (dysentery), Salmonella (typhoid) and enteroinvasive $E$. coli. Rotaviruses are most commonly found in diarrhoea of children and invade the small-intestinal epithelium. Acute diarrhoea is responsible for 3-4 million deaths annually worldwide, many of which are children, in which it accounts for $20-30 \%$ of all mortality.

Rotavirus is the most common cause of acute childhood diarrhoea. It is primarily seen in infants and young children, with a peak incidence between 6 months and 2 years of age. Rotaviruses invade the highly differentiated absorptive columnar cells of the small-intestinal epithelium, where they replicate. This results in partial distuption of the intestinal mucosa with loss of microvilli and decreased villus : crypt ratio. Rotavirus infection is associated with increased intestinal permeability. Jalonen et al. (1991) found increased lactulose:mannitol urinary recovery ratios in patients with acute diarrhoea compared with nondiarrhoeal patients. Concomitantly, the levels of immune complexes containing dietary $\beta$-lactoglobulin in sera were significantly higher in patients with rotavirus diarrhoea than in non-diarrhoeal patients. Enhanced macromolecular absorption in rotavirus gastroenteritis has been shown in several studies (Heyman et al. 1987; Isolauri et al. 1993a,b). A local immunoinflammatory reaction impairs the intestine's barrier function. Impaired barrier function and defective handling of intraluminal antigens in the epithelial cells may be an important pathogenic mechanism in acute and chronic gastrointestinal disorders. It may abrogate tolerance to ubiquitous antigens, 
including bacteria residing in the intestine (Duchmann et al. 1995).

Chronic infection of the gut is much rarer and seen only in persons who have anatomical abnormalities of the gut such as blind loops, strictures or fistulas. Chronic infection with Tropheryma whippelli causes Whipple's disease and intestinal bacteria are responsible for tropical sprue. Tuberculosis affects the gut, especially the ileo-caecal region, and chronic carrier states occur with amoebas.

The main indigenous bacteria of the large intestine resist invasion by pathogenic species and this is part of the human host defence against diarrhoeal illness. This barrier function provided by the gut flora may be impaired during antibiotic use, where diarrhoea is common. Antibiotic-associated diarrhoea is usually due to invasion with toxin-producing species such as Clostridium difficile or Clostridium septicum.

\subsection{Normal bowel habit (Cummings, 1993, 1994)}

Bowel habit is defined by the amount of stool passed, frequency of defecation and consistency of stool. It varies very widely throughout the world with daily stool weights in the range $100-400 \mathrm{~g} / \mathrm{d}$ and stool frequency of three times per day to three times per week. In European countries and North America, daily stool weight is of the order of 100-150 g/d (Cummings et al. 1992). Bowel habit is controlled principally by two factors, first diet, and second gut motor activity (transit time). The foods that affect bowel habit are those which reach the large intestine, i.e. are nondigestible. The dietary components falling into this category are lactose (in lactase-deficient individuals), sugar alcohols, non-digestible oligosaccharides, resistant starch and NSP. Dietary fat and protein have little effect on bowel habit unless they are rendered non-absorbable by some technique (e.g. sucrose polyester).

The mechanism by which non-digestible foods affect bowel habit depends on their fermentability. Foods that are not fermented appear in faeces and cause bulking depending on their inherent mass or water-holding capacity (i.e. bran and other intact cell-wall material). Most foods that reach the large intestine are fermented, yielding SCFA, which are absorbed and do not contribute to faecal bulk, and $\mathrm{H}_{2}$ and $\mathrm{CH}_{4}$, which can expand faecal bulk but not mass. Fermentation also stimulates bacterial growth to produce biomass, which is the principal mechanism of increasing stool mass. A final mechanism that needs to be borne in mind is the interrelationship between intestinal bulk and motor activity. As bulk in the large intestine increases, so motor activity is stimulated and, in general, the greater the bulk the more rapid the transit. Motor activity expressed as transit time may also modulate stool output independently of dietary bulk (Cummings, 1993, 1994).

\subsection{Constipation}

Constipation is a disorder of motor activity of the large bowel traditionally defined in terms of bowel frequency. The main symptom in constipation is straining at defecation, and discomfort, distension and incomplete rectal emptying are all considered part of the condition. Total gut transit time is generally prolonged in constipated subjects. There are many causes of constipation, with diet one of the common reasons, particularly low-NSP diets, gluten-free diets, 'low-residue' diets and enteral feeds. Treatment of simple constipation is usually in the first instance by dietary means. The principle is to increase fermentable carbohydrates in the diet, especially NSP from whole-grain cereals. Thus, diet has a major role to play in controlling bowel habit.

\subsection{Irritable bowel syndrome (IBS) (Thompson \& Heaton, 1980; Thompson \& Gomborone, 1993)}

IBS is one of the commonest disorders seen in the hospital gastroenterology clinic, but it is poorly understood. IBS (or irritable colon, mucus colitis, spastic colon) is a disorder of motor activity of the whole bowel, although colonic symptoms usually predominate. It occurs very widely throughout the world and is commoner in women. IBS has two main presenting features, abdominal pain and altered bowel habit (Thompson \& Heaton, 1980).

The cause of IBS is unknown but it occurs in many patients following dysentery or antibiotic use. In addition, patients often volunteer that specific foods upset them (food intolerance) and stress is clearly contributory. Wheat bran and other bulk laxatives are frequently given, but results have been very variable. They may aggravate symptoms through gas production, although in patients who are predominantly constipated they are of benefit. Because of a postulated disturbance in the colonic microflora in IBS a number of groups are currently trying the use of probiotics to 'normalize' the flora.

\subsection{Inflammatory bowel disease (Podolsky, 1991; MacDonald, 1993; Tytgat et al. 1995)}

Two major disorders, Crohn's disease and ulcerative colitis, are conventionally grouped together under the heading inflammatory bowel disease because both are characterized by chronic inflammation in the gut. However, it is best to consider them as separate conditions because they have characteristically different pathology, clinical courses, complications and management. The aetiology of neither is known.

5.5.1. Crohn's disease. Crohn's disease may affect any part of the gut from mouth to anus. Characteristically it occurs in the ileocaecal region and colon, and the inflammation is patchy or discontinuous. It frequently recurs after surgical resection of the affected areas of gut at or near the point of anastomosis of the bowel. The involved intestine is thickened, with ulceration of the mucosa, stricturing and fistula formation. Mouth ulcers and perianal abscesses are characteristic. Histologically there is transmural inflammation, with mononuclear cells, lymphoid aggregates and granulomata.

Crohn's disease occurs worldwide although it is uncommon in Central and South America, Africa and Asia. It is seen less frequently than ulcerative colitis, although rates have increased fivefold since 1950 . It is predominantly a disease of the young with peak occurrence between the ages of 20 and 30 years with a second peak between 70 and 80 years. The cause is unknown but genetic factors are 
important with $10 \%$ of patients having a close relative with the disease. Diet has been implicated, especially sugar, but a multicentre trial in which a diet excluding sugars and rich in NSP was given did not result in any conclusive benefit in patient management (Ritchie et al. 1987). More likely aetiological factors include bacteria and other micro-organisms.

Diet has an important role to play in the management of Crohn's disease. For patients who do not respond to conventional treatment in Crohn's disease, various enteral and parenteral regimens providing bowel rest have been used. The rationale for such treatments is that the absence of food antigens in the bowel lumen reduces inflammatory immune reactions, motor and digestive activity, and gives the mucosa a chance to heal itself.

Most patients relapse soon after introduction of normal food following bowel rest regimens. It has been suggested that dietary modification to exclude foods likely to cause symptoms (predominantly cereals, dairy products and meat) can lead to extended periods of remission.

5.5.2. Ulcerative colitis. Ulcerative colitis is a chronic inflammatory condition of the mucosa of the large bowel that causes bloody diarrhoea. It is one of the diseases of modern civilization, being first described with certainty in 1909 and predominantly affecting industrialized populations. It has an overall prevalence of 40-120 cases per 100000 of the population in Western countries and is uncommon, although beginning to emerge, in Africa and India. It affects the sexes equally and usually presents between the ages of 20 and 40 years.

Its cause is unknown but there is probably a genetic component, with a 15 -fold increased risk amongst close relatives of patients. Animal models point to an involvement of the immune system, but also to the necessary presence of bacteria in the colon to produce colitis. The observation that healthy colonocytes use butyrate for their metabolism and that this is defective in ulcerative colitis has raised the possibility of dietary factors in its aetiology. However, no convincing evidence for a dietary factor has emerged, although the inhibition of butyrate oxidation by S-compounds leaves the possibility of diet combining with the colonic microflora as a possible initiating factor of the inflammation (Pitcher \& Cummings, 1996).

\subsection{Food allergy (Isolauri, 1995)}

Food allergy is defined as an immunologically mediated adverse reaction against dietary antigens. Food allergy can affect several organ systems, the symptoms commonly arising from the gut, skin and respiratory tract. Despite the wide spectrum of clinical manifestations, there are at least two prerequisites for the development of food allergy: dietary antigens must penetrate the intestine's mucosal barrier, and the absorbed antigens must cause harmful immune responses. The immaturity of the immune system and the gastrointestinal barrier may explain the peak prevalence of food allergies in infancy. In food allergy, intestinal inflammation and disturbances in intestinal permeability and antigen transfer occur when an allergen comes into contact with the intestinal mucosa. During dietary elimination of the antigen, the barrier and transfer functions of the mucosa are normal. It has, therefore, been concluded that impairment of the intestine's function is secondary to an abnormal intestinal immune response to the offending antigens.

\subsection{Colorectal cancer (Faivre et al. 1985)}

Colorectal cancer is unequally spread throughout the world (Burkitt, 1971). It is amongst the three most common malignancies in most industrialized countries including Western Europe, and its survival rate has improved little during the past decades, being of the order of $40 \%$ at 5 years. The most common locations in high-risk countries are the left colon and the rectum, whereas right-colon cancers are proportionally more common in low-risk areas such as Japan. About $5 \%$ of colorectal cancers are truly genetic diseases (hereditary nonpolyposis colorectal cancer and familial polyposis coli), transmitted as autosomal dominant, but the majority of colorectal cancers are sporadic, and are mostly influenced by environmental factors, in particular diet, with a potential interaction between a genetic background and diet (Boutron et al. 1996). From 70 to $80 \%$ of left colon and rectal cancers in Western countries follow the so-called adenoma-carcinoma pathway, with possibly less in the case of right-colon cancers (Bedenne et al. 1992). This is of major importance as it provides the opportunity of studying precancerous lesions both in aetiological studies such as case-control and cohort studies, and for intervention studies, where studying adenoma recurrence or growth is easier and brings results more rapidly (Boutron \& Faivre, 1993).

\section{Methodology}

\subsection{Human intestinal microflora (Collins \& Gibson, 1998)}

The identification of factors controlling or influencing the composition of the human intestinal microflora, including prebiotics and probiotics, may be compromised by the precision of current methodologies for determining bacterial composition which are based almost entirely on phenotypic approaches. Whilst these have met with some success, when done properly, they are time-consuming, laborious and lack the resolving power necessary to analyse the complex microbiota at the species or subspecies level.

Traditional gut microbiological methodologies are usually based on morphological and biochemical properties of the organisms (Table 2): Whilst such an approach is costeffective and allows the processing of replicate samples, the procedures used may be unreliable and may lack resolution. For example, the metabolic plasticity of organisms is problematic and the test used may not be reproducible. Phenotypic characterization does not allow a high degree of fidelity and is most useful for genus level identification. In some cases this situation is eased if the test organism exhibits a specific metabolic trait. For example, bifidobacteria may be detected, on a qualitative basis, by the production of fructose-6-phosphate phosphoketolase activity. An additional problem is that traditional cultivationbased methods may result in underestimation of microbial diversity, due to the presence of organisms that cannot be 
Table 2. Methods for study of the human gut microbiota

\begin{tabular}{|c|c|c|}
\hline Method & Advantages & Disadvantages \\
\hline $\begin{array}{l}\text { Morphological and biochemical } \\
\text { characteristics }\end{array}$ & $\begin{array}{l}\text { Straightforward to carry out. Can run in } \\
\text { parallel a large number of replicates. } \\
\text { Relatively inexpensive }\end{array}$ & $\begin{array}{l}\text { Involves operator subjectively to recognize different } \\
\text { colonial and cellular morphologies. Lack of } \\
\text { discriminatory power and subject to metabolic plasticity } \\
\text { of the organisms. Applicable only to culturable bacteria }\end{array}$ \\
\hline $\begin{array}{l}\text { Specific biomarkers, e.g. certain } \\
\text { cell-wall antigens, cellular fatty } \\
\text { acids, plasmid profiles, } \\
\text { serotyping, resistance to } \\
\text { antibiotics }\end{array}$ & Cultural procedures may not be required & $\begin{array}{l}\text { Cannot assign the position of hitherto unknown species. } \\
\text { Relies on all test organisms having unique biomarker. } \\
\text { Stability of the biomarker may be questionable }\end{array}$ \\
\hline Ribotyping (RNA polymorphisms) & Reliable. Very high discriminatory power & $\begin{array}{l}\text { Applicable only to culturable forms. Cannot assign the } \\
\text { taxonomic position of any unknown species }\end{array}$ \\
\hline $16 S$ ribosomal RNA typing & $\begin{array}{l}\text { High fidelity. Reliable. Cumulative database } \\
\text { allows placement of unknown species. } \\
\text { Applicable to culturable and non-culturable } \\
\text { forms. Allows probe development }\end{array}$ & $\begin{array}{l}\text { Costly for both reagents and large-scale equipment, e.g. } \\
\text { automated sequencers. Recommended for partial use } \\
\text { only }\end{array}$ \\
\hline
\end{tabular}

cultivated, which therefore elude isolation. This has led to the development of alternative strategies for assessing microflora changes.

The detection of biomarkers that may be attributed to certain components of the flora offers some potential. However, to be wholly effective there would be a need for all the major bacterial components of interest to be separable by individual biomarkers, e.g. changes in cellular fatty acids. This may be feasible but would be difficult to prove in a reliable manner.

An attractive solution to the problem of determining microflora changes accurately, lies in the application of modern high-resolution molecular genetic techniques. Recent advances in the field of molecular biology are revolutionizing the characterization and identification of micro-organisms (Pace, 1996). For example, molecular sequence analysis, particularly of ribosomal RNA (rRNA), provides a powerful tool for determining the genetic interrelationships of micro-organisms, and allows systematic monitoring of the gut flora response to dietary intervention. By utilizing diagnostic sequences within the rRNA, it is possible to design gene probes that facilitate precise identification. The use of polymerase chain reaction technologies may also allow access to non-culturable micro-organisms. Over the next few years, $16 \mathrm{~S}$ rRNA sequence analysis is expected to rapidly advance our knowledge of the true genetic diversity of the gut microbiota, including organisms that evade traditional identification, due either to a lack of taxonomic resolution and/or non-culturability.

Molecular approaches have already been used to determine changes in the composition of the microbial gut flora (Langendijk et al. 1995; Kok et al. 1996; McCartney et al. 1996; Wilson \& Blitchington, 1996). Clearly, however, before such techniques are routinely used in gut microbiological applications, the fidelity and efficacy of such methods need to be rigorously evaluated. A comparative phylogenetic framework of gut micro-organisms, based on genetic material such as $16 \mathrm{~S}$ rRNA, would allow highly discriminatory and dependable diagnostic probes to be developed. Preferably, the probes should be validated using different procedures, such as in situ and dot blot hybridizations.
Another approach to analyse the genetic diversity of complex microbial populations is denaturing gradient gel electrophoresis or temperature gradient gel electrophoresis. The technique is based on the separation of polymerase chain reaction-amplified fragments of genes coding for $16 \mathrm{~S}$ rRNA, all of the same length (Muyzer et al. 1993). This results in unique separation patterns for different microbial populations, and will contribute to the description of changes or differences in microflora composition of uncharacterized microbial populations.

The potential benefits of such technologies in gut microbiology, especially dietary modulation for improved health, are large, particularly when used in conjunction with traditional phenotypic procedures. The use of molecular genetic approaches for qualitative and quantitative monitoring of the human intestinal microbiota will constitute an essential step forward for determining the validity of the functional food concept, when directed towards the role of the gut flora.

\subsection{Functional analysis of the gut microflora (Rowland, 1995)}

The complexity of the gut microflora, coupled with timeconsuming procedures necessary to identify and enumerate the anaerobic components, makes their characterization by conventional methodology difficult and expensive. In particular, such methods are not suited to studies involving large numbers of subjects or treatment regimens. Less comprehensive studies (e.g. identification of major groups) are open to the criticism that any induced changes occurring in genera or species other than those being enumerated will be missed. Furthermore, although bacteriological investigations are useful in describing the basic ecology of the gut, they are of less value in studies of metabolism, nutrition and cancer.

An alternative approach is to use biochemical assays that measure the functional activity of the flora as a whole and thus permit deductions to be made regarding the role of the flora in the metabolism of dietary components. In addition, by selecting microbial enzyme activities or metabolic endpoints resulting in compounds with potentially toxic or beneficial effects, probable health consequences for the host can be assessed. 
6.2.1. Bacterial enzymes. The bacterial enzymes commonly assayed include $\beta$-glucuronidase (EC 3.2.1.31), $\beta$ glucosidase ( $E C$ 3.2.1.21), azoreductase, nitroreductase, nitrate reductase ( $E C$ 1.7.99.4), the conversion of precarcinogen 2-amino-3-methyl-7H-imidazo[4,5- $f$ ]quinoline (IQ) to 7-hydroxy-2-amino-3,6-dihydro-3-methyl-7Himidazo[4,5- $f$ ] quinoline-7-one (7-OHIQ). The substrates of these enzymes and the functional and health implications of their products have been extensively reviewed (Rowland, 1995). For example, bacterial $\beta$-glucuronidase in the colon is able to release carcinogens from hepatically derived glucuronic acid conjugates and is a critical factor in the enterohepatic circulation of drugs and other foreign compounds. $\beta$-Glucosidase hydrolyses plant glycosides to release the aglycones, many of which are mutagenic, although some exert anti-carcinogenic activity (Rowland, 1995). Azo- and nitroreductases reduce their substrates to amines, which are usually more toxic than the parent compound, and nitrate reductase generates the highly reactive and toxic anion nitrite. Bacterial conversion to 7-OHIQ is one pathway of activation of the pre-carcinogen IQ (formed during cooking of meat and fish) to a genotoxic derivative.

6.2.2. Bacterial metabolites in faeces. Faecal metabolites that are indicators of bacterial activity relevant to colonic health include $\mathrm{NH}_{3}$, a toxic product of bacterial breakdown of protein and urea (Clinton, 1992), and phenols and cresols, which are derived from amino acid catabolism by gut bacteria (Macfarlane \& Macfarlane, 1995). The production of $\mathrm{NH}_{3}$ is closely related to bacterial activity and is associated with certain toxic events in the gastrointestinal tract. $\mathrm{NH}_{3}$ is considered to be a potential tumour promoter in the colon, and has been postulated to enhance neoplastic transformation in the gut.

Other gut bacterial products with possible adverse effects on the colonic mucosa include $N$-nitroso compounds, which are potentially carcinogenic substances formed by bacterial catalysis of the reaction of nitrite and nitrogenous compounds in the colon (Rowland, 1995), diacylglycerol, a putative tumour promoter derived from lipid breakdown, and secondary bile acids, deoxycholic and lithocholic acids, also putative tumour promoters.

6.2.3. Assessment of cytotoxicity, genotoxicity and mutagenicity of faeces. An alternative approach to assaying enzymes or metabolites in faeces is to assess toxicological activity of fractions using short-term tests for toxicity, genotoxicity and mutagenicity. This provides a direct estimate of the potential of the faecal sample to damage the colonic mucosa and has been used to provide insights into possible processes involved in colon cancer. Usually, the aqueous phase of human faeces (faecal water) is used (Rafter et al. 1987). Cellular toxicity can be assessed using rapid colorimetric assays in multiwell plates. For example the 3-[4,5-dimethylthiazol-2-yl]-2,5diphenyltetrazolium bromide (MTT) assay (Mosmann, 1983) involves the $\mathrm{pH}$-dependent conversion of water-soluble MTT to water-insoluble formazan and provides a reliable estimate of viable cell number.

Recently, using the Comet assay, it has been shown that the genotoxicity of faecal water varies markedly between individuals, with at least some of the DNA damage occurring via an oxidative mechanism (Venturi et al. 1997).

6.2.4. Susceptibility of functional markers to dietary change. In animal models, major changes in activities of bacterial enzymes and in levels of bacterial metabolic products have been seen after a wide range of dietary changes. These include the type and level of dietary fat and protein, supplementation with dietary fibre and resistant starch, and addition of oligosaccharides (Rowland, 1991). In many cases changes were seen in the absence of alteration in composition of the gut flora.

In contrast, modification by diet of bacterial metabolism in human subjects has proved more difficult. However, changes in enzyme activities and concentrations of $\mathrm{NH}_{3}$, phenol and cresol have been detected in volunteers consuming lactulose (Terada et al. 1992) and lactobacilli (Goldin \& Gorbach, 1984).

A low level of $\mathrm{NH}_{3}$ production in the gut is associated with low-protein, high-fibre diets, which appear to be protective against cancer of the colon. $\mathrm{NH}_{3}$ levels have been shown to be elevated in rats consuming a diet containing high-risk factors for colon cancer (Hambly et al. 1997).

The cytotoxicity of faecal water strongly correlates with bile acid concentration in faeces and is increased in individuals on high-fat diets (Rafter et al. 1987) and decreased in subjects on high-resistant-starch diets (van Munster et al. 1994).

\subsection{Digestibility and bioavailability of foods}

The methodology for studying non-digestibility of foods is an important area for understanding the effects of food and food components on intestinal microflora and physiology. A compilation of current methodology is given in Table 3. It is important to identify the nature of molecules, their chemical bonds and molecular size to understand digestibility. In vitro digestion studies and markers for absorption and excretion are of value. Animal models offer a means of simulating different digestion extremes and human volunteer studies enhance the understanding of in vivo digestibility of foods and bioavailability of nutrients.

\subsection{Large-bowel function}

Study of large-bowel function is extremely difficult, mainly because of its inaccessibility. However, the large bowel has unique aspects of metabolism; the principal events in the lumen are anaerobic and end-products such as $\mathrm{H}_{2}$ and SCFA are not produced by other biochemical reactions in the body. These products are absorbed and appear in blood and breath, and can be used to study intraluminal events. Many investigators have used faeces and their composition as a guide to intracolonic events. Such studies have often been criticized because of the lack of representativeness of faeces, but for some aspects of colonic metabolism, such as the gut microflora of the lumen, they are probably acceptable. The study of the large intestine has spawned a large number of in vitro models, particularly of fermentation. A short summary of methods is given in Table 4 . 
Table 3. Methods to study the digestibility and bioavailability of foods

\begin{tabular}{|c|c|c|}
\hline Method & Advantages & Disadvantages \\
\hline 1. Chemistry & $\begin{array}{l}\text { Identifies nature of molecules, chemical bonds, } \\
\text { molecular size, etc. (e.g. most } \beta \text {-glucans are not } \\
\text { digested) }\end{array}$ & $\begin{array}{l}\text { Requires dedicated carbohydrate chemistry } \\
\text { laboratory }\end{array}$ \\
\hline 2. In vitro model & Studies with pancreatic and other enzymes & $\begin{array}{l}\text { Care needed to mimic conditions in gut and hence } \\
\text { rate and extent of digestion }\end{array}$ \\
\hline 3. Blood appearance & $\begin{array}{l}\text { Glucose tolerance, chylomicrons. Applicable to a large } \\
\text { number of samples }\end{array}$ & $\begin{array}{l}\text { Requires human subjects and can be affected by } \\
\text { factors other than those determining digestion }\end{array}$ \\
\hline 4. Breath & $\begin{array}{l}\mathrm{H}_{2} \text { or } \mathrm{CH}_{4},{ }^{13} \mathrm{CO}_{2} \text {. Simple non-invasive for human } \\
\text { studies }\end{array}$ & $\begin{array}{l}\text { Difficult to quantify. Prolonged studies (16-24h) } \\
\text { needed for fermentation. Large subject variability }\end{array}$ \\
\hline 5. Ileostomy model & $\begin{array}{l}\text { Probably the gold standard for study of digestion in } \\
\text { stomach and small bowel }\end{array}$ & $\begin{array}{l}\text { Requires access to patient population. May } \\
\text { underestimate losses to caecum because of } \\
\text { microbial colonization of ileum and fermentation } \\
\text { in bag }\end{array}$ \\
\hline $\begin{array}{l}\text { 6. Intestinal intubation: } \\
\text { jejunum, ileum, colon, } \\
\text { perfusion/aspiration, single } \\
\text { or multilumen tubes }\end{array}$ & $\begin{array}{l}\text { Valuable for dynamic studies of flow rate, site of digestion } \\
\text { in small bowel, nutrient concentrations and physical } \\
\text { form, and identification of intermediate products of } \\
\text { digestion }\end{array}$ & $\begin{array}{l}\text { Very invasive human studies. Need X-ray control. } \\
\text { Presence of tube may alter normal physiology. } \\
\text { Difficult to make quantitative }\end{array}$ \\
\hline 7. Faecal analysis & $\begin{array}{l}\text { Relatively straightforward and gold standard for overall } \\
\text { digestion and fermentation }\end{array}$ & $\begin{array}{l}\text { Requires accurate faecal collections with balance } \\
\text { markers and good methods validated for faeces }\end{array}$ \\
\hline 8. In vitro fermentation & $\begin{array}{l}\text { Various batch and continuous culture methods available. } \\
\text { Good for modelling physiology }\end{array}$ & Needs well-founded microbiology laboratory \\
\hline $\begin{array}{l}\text { 9. Animal models: } \\
\text { germ-free/conventional, } \\
\text { fistulated }\end{array}$ & $\begin{array}{l}\text { Gives greater access to tissues. Germ-free, human } \\
\text { associated and conventional flora }\end{array}$ & Animal facilities needed. Extrapolation to man \\
\hline
\end{tabular}

Table 4. Methods for studying large-bowel function

\begin{tabular}{|c|c|}
\hline Focus of study & Method \\
\hline $\begin{array}{l}\text { Bowel habit } \\
\text { Motor function }\end{array}$ & $\begin{array}{l}\text { Diary record } \\
\text { Motility recording } \\
\text { Recto-anal manometry and pelvic floor } \\
\text { neurophysiology } \\
\text { Transit time: } \\
\text { whole gut - non-absorbable markers } \\
\text { Partial transit time: } \\
\text { small bowel - isotope-labelled meal and } \\
\quad \text { gamma scanning } \\
\quad \text { lactose breath } \mathrm{H}_{2} \\
\text { large bowel } \\
\text { - X-ray following marker ingestion }\end{array}$ \\
\hline Faecal analysis & $\begin{array}{l}\text { Microflora, and enzymic activities } \\
\text { Fat, } \mathrm{N} \text {, biomass, carbohydrate, DM, bile acids, } \\
\text { sterols, pH } \\
\text { Faecal water: osmolarity, pH } \\
\text { electrolytes } \\
\text { bile acids } \\
\text { genotoxicity/cytotoxicity }\end{array}$ \\
\hline In vitro models & $\begin{array}{l}\text { Occult blood } \\
\text { Transport physiology } \\
\text { Batch cultures, single chemostats, } \\
\text { multi-chamber chemostats }\end{array}$ \\
\hline $\begin{array}{l}\text { Blood (including } \\
\text { portal blood) } \\
\text { Breath } \\
\text { Mucosal biopsies } \\
\text { Exfoliated cells }\end{array}$ & $\begin{array}{l}\text { Short-chain fatty acids, branched-chain fatty } \\
\text { acids, bile acids } \\
\mathrm{H}_{2}, \mathrm{CH}_{4},{ }^{13} \mathrm{CO}_{2} \\
\text { General histology and immuno-staining } \\
\text { DNA adducts } \\
\text { Mutational analysis (e.g. Kras) } \\
\text { Proliferation markers } \\
\text { Genotyping } \\
\text { Apoptosis }\end{array}$ \\
\hline Mucus & $\begin{array}{l}\text { Composition and structure } \\
\text { Thickness } \\
\text { Breakdown }\end{array}$ \\
\hline X-ray & $\begin{array}{l}\text { Barium studies } \\
\text { Plain film of abdomen }\end{array}$ \\
\hline Endoscopy & $\begin{array}{l}\text { Proctoscopy } \\
\text { Sigmoidoscopy (including flexible) } \\
\text { Colonoscopy }\end{array}$ \\
\hline $\begin{array}{l}\text { Angiography } \\
\text { Radiotelemetry }\end{array}$ & $\begin{array}{l}\text { Vasculature } \\
\text { pH } \\
\text { Motility }\end{array}$ \\
\hline
\end{tabular}

\subsection{Gut-associated lymphoid tissue}

The presence of the digestive flora has a considerable influence on the immune system of the host (see section 3.5) and the principal methodology to study this is the use of germ-free animals, also termed axenic animals. By comparing germ-free and conventional animals, it is possible to highlight the role of the digestive flora in immune function. Moreover, the role played by bacteria isolated from the digestive flora, or used as probiotics, can be analysed by inoculating the gut of germ-free animals with these bacteria. These are called gnotobiotic animals. Recently, germ-free mice associated with human flora have been developed allowing in vivo studies of functional properties of probiotics and prebiotics used in human nutrition.

The advantages of gnotobiotic animal studies are to determine which kind of immune response a given bacteria established in the gut is able to exert, e.g. non-specific and/or specific immune response; inductive or suppressive immune response. Many methodologies are available. They are summarized in Table 5 and marked with $(\mathrm{H})$ when they are applicable to human studies. The disadvantages of gnotobiotic models are the expensive animal facilities they need and the limits of the animal species studied. Moreover, it is not certain that a modulating bacterial effect observed in gnotobiotic conditions will be expressed in conventional conditions. Thus, other studies using conventional animals are needed. Current methods utilize in vitro cultures of systemic or intestinal lymphoid cells (De Simone et al. 1993), cellular assays with colonic cell lines (Schiffrin et al. 1995) and in vivo assays with conventional animal models (Perdigon et al. 1996). Two types of specific immune response can be assessed at the intestinal level. These include the suppression of humoral and cellular immune responses to chronically administered antigens at the systemic level (immune regulation) and the induction of a protective IgA antibody response at the mucosal level 
Table 5. Selected methods to study intestinal immune function

\begin{tabular}{|c|c|c|c|}
\hline Immune response & Methodology & Advantages & Disadvantages \\
\hline Proliferative assays & $\begin{array}{l}\text { In vitro: measurement of the } \\
\text { proliferation of systemic or } \\
\text { intestinal lymphoid cells after } \\
\text { stimulation with mitogens or } \\
\text { cell components }\end{array}$ & $\begin{array}{l}\text { Easy for systemic assays: from } \\
\text { blood samples }(H)\end{array}$ & $\begin{array}{l}\text { Not easy for intestinal assays in } \\
\text { human subjects: need biopsy } \\
\text { Technical difficulties } \\
\text { Need correlation with in vivo } \\
\text { assays to give a } \\
\text { biological significance }\end{array}$ \\
\hline Cytokine production & In vitro: after proliferative assays & $\begin{array}{l}\text { Development of new } \\
\text { methodologies }(H) \\
\text { Biomarkers }(H)\end{array}$ & $\begin{array}{l}\text { Need correlation with in vivo } \\
\text { assays to give a biological } \\
\text { significance }\end{array}$ \\
\hline Phagocytic activity & $\begin{array}{l}\text { In vitro: peritoneal cells, } \\
\text { circulating cells }\end{array}$ & $\begin{array}{l}\text { Easy for systemic assays: from } \\
\text { blood samples }(H)\end{array}$ & $\begin{array}{l}\text { Correlation with specific immune } \\
\text { response poorly understood } \\
\text { Technical difficulties for intestinal } \\
\text { phagocytes }\end{array}$ \\
\hline $\begin{array}{l}\text { Modulation of molecular } \\
\text { expression in intestinal cell } \\
\text { lines }\end{array}$ & $\begin{array}{l}\text { In vitro: } \mathrm{HT}-29, \mathrm{CaCo}-2 \text { cell line } \\
\text { cultures } \\
\text { Facs analysis, histochemical } \\
\text { methods }\end{array}$ & $\begin{array}{l}\text { Cell lines originated from human } \\
\text { intestine } \\
\text { Specialized line cells }\end{array}$ & $\begin{array}{l}\text { Adenocarcinoma lines } \\
\text { Absence of correlation with } \\
\text { intestinal cellular environment }\end{array}$ \\
\hline \multirow[t]{6}{*}{ IgA antibody response } & $\begin{array}{l}\text { Measured by ELISA or ELISPOT } \\
\text { at several levels: }\end{array}$ & Biomarkers & \\
\hline & $\begin{array}{l}\text { (1) In serum: soluble IgA } \\
\text { antibodies }\end{array}$ & Easy in human subjects $(H)$ & $\begin{array}{l}\text { Does not reflect the intestinal } \\
\text { response }\end{array}$ \\
\hline & $\begin{array}{l}\text { (2) In blood: circulating IgA- } \\
\text { producing cells }\end{array}$ & Reflects intestinal response $(\mathrm{H})$ & $\begin{array}{l}\text { Does not reflect transepithelial } \\
\text { transport into gut lumen }\end{array}$ \\
\hline & (3) In faeces & Easy, allows kinetic studies $(H)$ & $\begin{array}{l}\text { Individual and daily variations, } \\
\text { proteolytic activity, reflects only } \\
\text { colonic response }\end{array}$ \\
\hline & (4) In saliva & Easy $(H)$ & Individual and daily variations \\
\hline & (5) Whole gut lavage fluid & $\begin{array}{l}\text { Invasive, but avoids intestinal } \\
\text { biopsy }(H)\end{array}$ & Needs hospitalization \\
\hline \multirow[t]{4}{*}{ Oral tolerance to dietary antigens } & $\begin{array}{l}\text { Ex vivo: proliferative assays of } \\
\text { lymphoid blood cells with } \\
\text { specific antigen }\end{array}$ & $\begin{array}{l}\text { Direct measure of the } \\
\text { unresponsiveness state }(H)\end{array}$ & \\
\hline & $\begin{array}{l}\text { Inflammatory cytokine production } \\
\text { by lymphoid blood cells }\end{array}$ & Biomarkers: TNF- $\alpha(H)$ & $\begin{array}{l}\text { Cause or consequence of oral } \\
\text { tolerance breakdown? }\end{array}$ \\
\hline & In vivo: intestinal permeability & $\begin{array}{l}\text { Increase in food } \\
\text { hypersensitivities }(H)\end{array}$ & $\begin{array}{l}\text { Not specific to immunological } \\
\text { changes }\end{array}$ \\
\hline & In vitro: Ussing chamber & $\begin{array}{l}\text { Direct correlation with antigen } \\
\text { transfer }\end{array}$ & Invasive and difficult technology \\
\hline
\end{tabular}

$H$, applicable to human studies; IgA, immunoglobulin A; TNF- $\alpha$, tumour necrosis factor- $\alpha$; Facs, fluorescence-activated cell-sorting; ELISPOT, enzyme-linked immunospot assay.

(immune exclusion). The definition of biomarkers is still incomplete. Several methodologies have been developed for IgA response measurements. Sampling needs blood collection or intestinal biopsies or stool and saliva collection. Problems in faeces and saliva handling and daily variations in expression of IgA activities have not been solved. In the case of oral tolerance, the biomarkers available in human subjects are defined as the absence of proliferation of cultured blood cells with antigen or down-regulation of inflammatory cytokines involved with food allergies (Benlounes et al. 1996; Sütas et al. 1996a, b). Other methodologies must be developed according to further knowledge about oral tolerance mechanisms (Weiner et al. 1994).

\subsection{Epithelial cell proliferation and colon carcinogenesis}

6.6.1. Biological markers for colorectal carcinogenesis. A relationship between colorectal carcinogenesis and abnormal cell proliferation has been demonstrated (Lipkin, 1988 ) in studies of the mucosa in patient groups at high risk of cancer, e.g. ulcerative colitis and familial adenomatous polyposis, and in animals exposed to carcinogens that target the colon. Two changes in colonic cell proliferation have been described (Risio, 1992): an increase in the total number of proliferating cells, or hyperproliferation, which is not a specific marker of cancer risk, and a progressive shift of proliferating cells to the crypt surface (stage II abnormality) which is more specific for tumour risk.

6.6.2. Cell proliferation. Several techniques have been developed to measure cell proliferation in colonic mucosa and assess the influence of diet. Measurement of crypt-cell production rate in microdissected crypts is considered to provide the best assessment of proliferation with the fewest artifacts. However, since it requires in vivo treatment with vincristine, it is not suitable for human studies.

Change in the rate of cell proliferation in the normal mucosa may be less reliable as a biomarker for diet-related cancer risk (Wasan \& Goodlad, 1996) and is just one of the processes contributing to colonic mucosal crypt architecture. Other events are differentiation, exfoliation and apoptosis. It is likely that the best predictor of cancer risk is an overall assessment of these events.

Markers of early epithelial events have been used in animal models. These include DNA damage, microadenomas and aberrant crypt foci in the mucosa. The microgel electrophoresis (Comet) assay has been used for assessing 
DNA damage in the colonic mucosa. Induction of aberrant crypt foci has been particularly widely used, as it is easy to observe macroscopically. However, its reliability as a marker of colorectal tumour risk is a matter of debate. In man, aberrant crypts and microadenomas, similar to those described in animals, have been described (Roncucci, 1992) but their correlation with other well-known markers of risk has not been established. Other markers of cell proliferation include PCNA and Mib 1; both are proteins appearing at specific stages in the cell cycle.

6.6.3. Differentiation. Methods exist to measure the state of differentiation of the mucosal epithelial cells by histochemical staining of mucins using binding to specific lectins. The methods can be applied to tissue sections from human and animal biopsies after fixation. Such approaches have been used to study colonic epithelium in rats and human subjects at various stages of neoplasia. They have not achieved widespread use for investigating dietary modification of neoplastic processes.

6.6.4. Apoptosis. Identification of oligonucleotide fragments by in situ end labelling using immunoperoxidase techniques forms the basis for various methods that can be applied to sections of colonic tissue from human subjects and animals and to cell suspensions (Ansari et al. 1993). Apoptosis in cell cultures from transformed colon tissues has been determined by measuring cell loss from monolayers (Hague et al. 1993).

6.6.5. Products used in experimental carcinogenesis (Martin et al. 1981). Spontaneous colorectal cancer is exceptional in animal models, but tumours can be created easily in rats, mice or hamsters using chemicals such as $N$-methylnitrosourea and $N$-methyl- $N^{\prime}$-nitro- $N$-nitrosoguanidine (Table 6). These products are direct carcinogens, which explains their local efficacy and their specificity when administered intra-rectally. Others such as 1,2-dimethylhydrazine or azoxymethane must be first metabolized by the liver, then at the level of the target cell, in order to be carcinogenic.

1,2-Dimethylhydrazine and derived azo and azoxy alkanes represent the carcinogens most commonly used to induce intestinal carcinomas in rats, mice and hamsters, by the oral or subcutaneous route. In rats, precancerous lesions such as adenomas are exceptional, cancers arising most commonly without any precursor adenoma, which is the opposite to what is observed in man. In mice, it is easier to induce adenomas than carcinomas (Maskens, 1976).
Secondary bile acids are cocarcinogens. They have been shown to promote colorectal carcinogenesis in animal models by increasing tumour formation rate induced by carcinogens, or increasing colonic cell hyperproliferation through the production of diacylglycerol and stimulation of protein kinase.

6.6.6. Types of lesion (Weisburger, 1973). The most studied lesion is adenocarcinoma induced either directly or, more often, indirectly. When azoxymethane is used by the subcutaneous or intramuscular route, intestinal carcinomas are formed in $100 \%$ of cases. Small doses induce tumours in the proximal colon and the caecum, whereas larger doses produce tumours mainly in the distal colon. Such tumours arise on flat mucosa and form plaques, thus mimicking human infiltrating tumours, which arise without any detectable adenomatous tissue and are named de novo cancers. However, this type of tumour is rare in human carcinogenesis, particularly in Western countries where tumours are mainly of the fungating type and arise in a pre-existing adenoma. Aberrant foci are interesting to study as they can be easily observed macroscopically. After a single injection of azoxymethane, aberrant foci have been described after early slaughter of the animals. These lesions are considered by some authors to be an early marker of tumour risk. They are more common in the rectum ( $90 \%$ of animals) than the caecum $(10 \%$ of animals), but tend to migrate with time, with a decrease in rectal lesions and an increase in caecal lesions after 4 weeks.

Changes in colonic cell proliferation, which will be described in man elsewhere, are largely used to test the protective effect of products, e.g. $\mathrm{Ca}$, against secondary bile acid-induced proliferation.

6.6.7. Transgenic mouse models for colon cancer studies. A number of inbred mouse models carrying germ-line mutations at the $A p c$ gene (the murine homologue of $A P C$, which is mutated in patients with familial adenomatous polyposis) have been developed. These animals exhibit spontaneous tumours throughout the intestinal tract, usually in the first few months of life. They are of use in studies of the interaction of diet and colon cancer and provide a model that dispenses with the need for chemical induction of carcinogenesis. The susceptibility of tumour incidence in these mice to dietary modulation is under investigation in a number of laboratories. Table 7 lists four such mouse models in current use.

Table 6. Current methods for studying colon carcinogenesis in animals

\begin{tabular}{llc}
\hline Products & \multicolumn{1}{c}{ Route } & Lesions \\
\hline $\begin{array}{c}\text { MNNG ( } N \text {-methyl- } N^{\prime} \text {-nitro- } N \text { - } \\
\text { nitrosoguanidine) and MNU } \\
(N \text {-methylnitrosourea) } \\
\text { DMH (1,2-dimethylhydrazine) }\end{array}$ & Intra-rectal instillations & $\begin{array}{c}\text { Colon adenocarcinomas, squamous } \\
\text { cell anal carcinomas, spleen and } \\
\text { liver haemangiomas } \\
\text { Multiple colorectal adenocarcinomas } \\
\text { and a few adenomas in rats }\end{array}$ \\
Azo and azoxy alkane derivatives & Oral or subcutaneous & $\begin{array}{c}\text { Subcutaneous or intramuscular } \\
\text { carcinomas; adenocarcinomas in } \\
\text { plaques }(d e \text { novo) }\end{array}$ \\
Secondary bile acids & Intra-rectal or oral & $\begin{array}{c}\text { Alone: colonic cell hyperproliferation } \\
\text { After DMH: increased number of } \\
\text { carcinomas }\end{array}$ \\
\hline
\end{tabular}


Table 7. Transgenic mouse models currently in use in colon cancer studies

\begin{tabular}{|c|c|c|}
\hline Model & Mutation & $\begin{array}{l}\text { Tumour yield } \\
\text { per animal }\end{array}$ \\
\hline $\begin{array}{l}\text { Min (multiple } \\
\text { intestinal } \\
\text { neoplasia), usually } \\
\text { used in the hetero- } \\
\text { zygous cross with } \\
\text { C57B16/J mice }\end{array}$ & $\begin{array}{l}\text { Germline nonsense } \\
\text { mutation at } \\
\text { codon } 850 \text { of } A p c\end{array}$ & $\begin{array}{l}\text { About } 100 \\
\text { adenomas with } \\
\text { the majority in the } \\
\text { small intestine }\end{array}$ \\
\hline Apc1638N & $\begin{array}{l}\text { Apc disrupted at } \\
\text { codon } 1638, \\
\text { probably leading } \\
\text { to a null allele for } \\
\text { Apc }\end{array}$ & $\begin{array}{l}\text { About five intestinal } \\
\text { tumours }\end{array}$ \\
\hline Apc $1638 T$ & $\begin{array}{l}\text { Apc disrupted at } \\
\text { codon } 1638 \\
\text { leading to a } \\
\text { truncated } \\
\text { polypeptide }\end{array}$ & $\begin{array}{l}\text { No intestinal } \\
\text { tumours at } 5 \\
\text { months }\end{array}$ \\
\hline Apc $\Delta 716$ & $\begin{array}{l}\text { Apc disrupted at } \\
\text { codon } 716, \\
\text { leading to a } \\
\text { truncated protein }\end{array}$ & $\begin{array}{l}200-500 \text { intestinal } \\
\text { adenomas }\end{array}$ \\
\hline
\end{tabular}

6.6.8. Limits of experimental models (Maskens \& Dujardin Loits, 1981). Experimental carcinogenesis in animals creates mainly infiltrating de novo carcinomas, and is an indirect process in most cases, i.e. multiple metabolic transformations are needed, the last occurring in the colon itself and involving bacterial enzymes such as $\beta$ glucuronidase, azoreductase or nitroreductase. In man, in particular in high-risk countries such as Western Europe, North America or Australia, most colorectal tumours are polypoid, fungating, and arise on a pre-existing adenoma. It has been estimated that, in the distal colon and rectum, where most tumours arise, over $80 \%$ of cancers arise through the adenoma-carcinoma pathway. Indirect evidence, such as the type of mutation of the p53 protein, points to a major role played by secondary bile acids, i.e. endogenous carcinogenesis, whereas carcinogenesis in animals is called exogenous carcinogenesis. The role of the latter may be more important in low-risk countries such as Japan, but is likely to be of little importance in high-risk countries. Therefore, it is difficult to extrapolate from animal models to man, in particular regarding the importance of bacterial enzymes, apart from the major role played by the $7 \alpha$-dehydroxylase, which converts primary into secondary bile acids.

\section{Human studies on the effects of food and food components}

Among the components likely to be used in functional foods, prebiotics and probiotics are already used as food ingredients.

Probiotics have been variously defined (Fuller, 1991, 1992; Havenaar \& Huis in't Veld, 1992) largely on the basis of their initial use in animal feeds. For the purposes of human nutrition we suggest that a probiotic is best defined as 'a live microbial food ingredient that is beneficial to health'.
A prebiotic is a 'nondigestible food ingredient that beneficially affects the host by selectively stimulating the growth and/or activity of one or a limited number of bacteria in the colon, that have the potential to improve host health' (Gibson \& Roberfroid, 1995).

Another approach is the use of synbiotics. A synbiotic has been defined as 'a mixture of probiotics and prebiotics that beneficially affects the host by improving the survival and implantation of live microbial dietary supplements in the gastrointestinal tract, by selectively stimulating the growth and/or activating the metabolism of one or a limited number of health-promoting bacteria, and thus improving host welfare' (Gibson \& Roberfroid, 1995).

\subsection{Prebiotics (Gibson \& Roberfroid, 1995)}

The key criterion for a food ingredient to be classified as a prebiotic is selective stimulation in human subjects of the growth of potentially beneficial bacteria in the gut. A prebiotic may repress pathogen growth or virulence and induce systemic effects that can be beneficial to health.

The prebiotics identified today and which have served to introduce the concept (Gibson \& Roberfroid, 1995) are nondigestible oligosaccharides that are fermented in the colon. They are obtained either by hot-water extraction from plants, eventually followed by enzymic hydrolysis of the extracted molecules, or synthesis from a disaccharide using -osyl transferases. The prebiotics that are available in Europe at present or that are being developed, belong to two groups, characterized by the major -osyl monomer they are composed of; namely, the fructosyl prebiotics (fructooligosaccharides) and the galactosyl prebiotics (galactooligosaccharides). Daily intake of fructosyl prebiotics for a few weeks leads to a selective stimulation of the growth of bifidobacteria. Many studies using different dose regimens and different methods of microbial analysis have shown selective stimulation of bifidobacteria (Roberfroid et al. 1997). Ito et al. (1993) have reported the same effect for galactosyl prebiotics. In addition, the experiments reported by Gibson et al. (1995) demonstrate that the growth of bifidobacteria is accompanied by a reduction in the number of other populations, e.g. bacteroides, clostridia and fusobacteria, thus leading to a major modification in the composition of the colonic microflora. Lactitol (4- $O-\beta-\mathrm{D}$ galactopyranosyl-D-glucitol) has been shown to have prebiotic properties (Ballongue et al. 1997).

The nutritional properties of prebiotics have been summarized in the report of an International Life Sciences Institute (ILSI) Europe workshop entitled Colonic Microflora: Nutrition and Health (Roberfroid et al. 1995) and in the proceedings of the 1st International Conference on East-West Perspectives in Functional Foods organized by ILSI (Roberfroid, 1996). In a recent monograph, Cummings (1997) also reviewed the nutritional properties of prebiotics.

The health-promoting consequences of prebiotic fermentation include increased faecal biomass and consequently stool weight and/or stool frequency (Roberfroid et al. 1993; Gibson et al. 1995). Colonic fermentation of prebiotics produces SCFA mainly acetate, propionate and butyrate (Roland et al. 1995). Through fermentation and absorption of SCFA prebiotics have part of their energy salvaged. Their 
digestible energy is of the order of $4-9 \mathrm{~kJ} / \mathrm{g}(1-2 \mathrm{kcal} / \mathrm{g})$ (Roberfroid et al. 1993; Molis et al. 1996). This property has led to their use as bulking ingredients, sugar substitutes and, for inulin, as a fat replacer (Coussement, 1996).

\subsection{Probiotics (Salminen et al. 1996a,b,c)}

The bacterial genera most often used as probiotics are lactobacilli and bifidobacteria. They can be given with fermented foods such as yoghurt, fermented vegetables or meats and they may briefly establish in the gut. A number of health-related effects are documented. Such established effects are listed in Table 8 and each effect has been shown in at least two human clinical studies by different research groups.

Colonic fermentation has been shown to be altered following probiotic intake either as fermented milks or freeze-dried cultures. Japanese studies have shown that oral administration of certain lactic-acid bacteria increases the numbers of endogenous lactobacilli in faeces. Similarly, an increase in faecal bifidobacteria has been observed, and the numbers of clostridia have decreased (Hosoda et al. 1994; Benno et al. 1996). Recent studies by Alander et al. (1996) have indicated that the potential to colonize human colonic mucosa differs from that of faecal samples. Thus, more human studies are clearly needed to understand changes in both colonic microflora and colonic mucosal microflora during probiotic intake.

7.2.1. Alleviation of lactose intolerance symptoms. The majority of the world's population have low levels of $\beta$ galactosidase in their small-bowel mucosa. Most lactasedeficient people are symptom-free if they consume only limited amounts of milk, except those subjects who are severely lactose intolerant. A beneficial effect of probiotics on lactose digestion has been demonstrated (Sanders, 1993). In particular, in studies comparing yoghurt and milk consumption it was shown that yoghurt consumption enhances lactose digestion in lactase-deficient subjects (Kolars et al. 1984; Marteau et al. 1990) and slows orocaecal transit.

7.2.2. Immune enhancement. An enhancement of the circulating IgA antibody secreting cell response was observed in infants supplemented with a strain of Lactobacillus casei, and was correlated with shortened duration of diarrhoea in the study group when compared with a placebo group (Kaila et al. 1992). Other studies reported an enhancement in the non-specific immune phagocytic activity of granulocyte populations in the blood of human volunteers after consumption of Lactobacillus acidophilus and Bifidobacterium bifidum (Schriffin et al. 1995; Marteau

Table 8. Health-related effects of currently available probiotics (for detailed references, see Marteau \& Rambaud, 1993; Lee \& Salminen, 1995; Salminen et al. 1996a, b, c)

Alleviation of symptoms of lactose intolerance Immune enhancement

Shortening the duration of rotavirus diarrhoea

Decreasing faecal mutagenicity

Decreasing faecal bacterial enzyme activity

Prevention of recurrence of superficial bladder cancer et al. $1997 a, b)$. Since phagocytic activity is involved with natural immunity and phagocytes are implicated in antibody immune responses as antigen-presenting cells, it is possible that stimulation of intestinal $\operatorname{IgA}$ antibody responses induced by lactic-acid bacteria may be explained partly by an effect on phagocyte cell functions. Ingestion of yoghurt has been reported to stimulate cytokine production, including interferon- $\gamma$ in human blood mononuclear cells (Solis-Pereyra \& Lemonnier, 1996).

7.2.3. Acute gastroenteritis. Several studies, by different groups and in different conditions, have shown that some probiotic lactobacilli significantly shorten the duration of rotavirus diarrhoea in developed (Guarino et al. 1977) and developing countries (Raza et al. 1995; Pant et al. 1996). For one strain, a similar clinical effect on the duration of rotavirus diarrhoea without an increase in immune response has been reported (Shornikova et al. 1997). Bifidobacterium bifidum (now reclassified as Bifidobacterium animalis) has been reported to prevent rotavirus diarrhoea (Saavedra et al. 1994).

7.2.4. Faecal mutagenicity and enzymes. Lactic acid bacteria influence the mutagenicity of intestinal contents and the levels of faecal microbial enzymes, such as $\beta$ glucuronidase, $\beta$-glucosidase, nitroreductase and urease (EC 3.5.1.5). Lactobacillus acidophilus has been shown to decrease faecal and urinary mutagenicity in healthy volunteers consuming fried minced beef. The same strain decreased faecal $E$. coli levels in colon-cancer patients and reduced faecal $\beta$-glucuronidase levels. Similar results have been reported for many probiotic lactobacilli strains (Goldin \& Gorbach, 1984; Goldin et al. 1992; Ling et al. 1994; Morotomi, 1996).

The prophylactic effects of oral administration of a lactobacillus strain on the recurrence of superficial bladder cancer have been reported in two Japanese studies (Aso \& Akazan, 1992; Aso et al. 1995).

\subsection{Diet and colon cancer}

The principal risk factors for sporadic colorectal cancer are high intakes of animal fat and meat, particularly red meat, excess energy intake, high intakes of refined cereals and of alcohol, particularly beer for colorectal carcinogenesis, and lack of physical exercise. A number of dietary factors have been proposed as potentially protective (Potter et al. 1993).

7.3.1. Dietary protective factors. A high intake of vegetables and fruit is associated with a decreased risk of colorectal cancer and adenomas throughout the world (Trock et al. 1990). Although vegetables such as the cruciferae may have a specific protective affect via antioxidant substances such as indoles, all fresh vegetables seem to be protective, in particular against cancer of the distal bowel. Components of fruit and vegetables that have been implicated as protective against colorectal cancer include NSP (dietary fibre), micronutrients (vitamins C, D and $\mathrm{E}, \beta$-carotene, $\mathrm{Ca}$ and $\mathrm{Se}$ ), glucosinolates, phenols, lignans, flavonoids and isoflavonoids.

One of the most important protective components of vegetables and unrefined cereals is dietary fibre. The mechanism may be through a diluting effect of carcinogens, a reduction in transit time, fermentation and the production 
of SCFA and alterations in $\mathrm{N}$ and bile acid metabolism. Although results of individual case-control studies have been disappointing, a meta-analysis of thirteen of these studies (Howe et al. 1992) found a significant inverse association between fibre intake and risk of colorectal cancer with a relative risk close to 0.5 for consumers of over $27 \mathrm{~g} / \mathrm{d}$. When extrapolating these data to the American population, the authors estimated it to be possible to reduce the risk of colorectal cancer by $31 \%$ i.e. 50000 cases per year by increasing the daily consumption by $13 \mathrm{~g}$. However, the multiplicity of methods for assessing dietary fibre intake in these studies makes any quantitative recommendations difficult.

$\mathrm{Ca}$ and vitamin $\mathrm{D}$ are other potentially protective factors that could easily be used as preventive agents. A recent American cohort study summarized the relations between $\mathrm{Ca}$, vitamin $\mathrm{D}$ and dairy products (Bostick et al. 1993). Of thirteen studies (nine case-control and four intervention studies), eight suggested an inverse relationship, which was statistically significant in five. Most studies that observed a protective effect of $\mathrm{Ca}$ came from Nordic or Anglo-Saxon communities, whereas no study demonstrated a protective effect of $\mathrm{Ca}$ or dairy products in Latin communities. It can, therefore, be suggested that the way $\mathrm{Ca}$ is consumed, and perhaps the general level of Ca consumption, is of importance. It has been suggested that fermented dairy products could be protective. In a French study (Boutron et al. 1996), a reduced risk of large adenomas was associated with a moderate intake of yoghurt.

Other dietary protective factors which have been investigated in intervention studies of recurrence of adenomas are the so-called antioxidant vitamins. The results of these studies have so far been disappointing (Greenberg et al. 1994; MacLennan et al. 1995).

\section{Safety issues \\ (Donohue \& Salminen, 1996; Roberfroid et al. 1997)}

Safety issues with new prebiotics and probiotics, including genetically modified bacteria, should be assessed according to European Union Novel Food Regulations on a case-bycase basis. Safety aspects of currently used prebiotics and probiotics are discussed in relation to their physiological properties.

\subsection{Prebiotics (Van Loo et al. 1995)}

Although the European Union regulation on novel foods and novel food ingredients leaves room for interpretation, it is very likely that most prebiotics placed into the European market after this regulation comes into force will fall within its scope. They will, therefore, be subject to safety and nutritional evaluation on a case-by-case basis.

Fructosyl-type ingredients, for which prebiotic properties are claimed, are already in the market. Fructosyl-type ingredients are natural components of a variety of fruits, vegetables and cereals, and consequently are consumed regularly (a few $\mathrm{g} / \mathrm{d}$ ) as part of the current diet (Van Loo et al. 1995). They are classified as natural food ingredients and cleared as novel food ingredients. Similarly galactosyl prebiotics have been cleared as novel food ingredients by the Health Department of The Netherlands (Staatscourant, 1996).

\subsection{Probiotics}

(Adams \& Marteau, 1995; Donohue \& Salminen, 1996)

The use of lactic acid-producing bacteria in foods has a long history and most strains are considered commensal micro-organisms with little or no pathogenic potential. Their ubiquitous presence in intestinal epithelium and the human gastrointestinal tract, and their traditional use in fermented foods and dairy products attest to their safety. Members of the genus Lactobacillus are most commonly given safe or generally recognized as safe (GRAS) status, whereas members of the genera Streptococcus and Enterococcus contain many opportunistic pathogens.

Case reports from the literature of lactic acid-producing bacteria causing clinical infection in human subjects have recently been analysed in reviews by Gasser (1994) and by Aguirre \& Collins (1993). Both reviews conclude that, considering their widespread consumption, lactic-acid bacteria appear to have a very low pathogenic potential. Two recent Finnish studies confirm that the number of infections associated with lactic-acid bacteria is extremely small and no case could be linked to commercial probiotics (Saxelin et al. 1996a,b).

\section{Critical evaluation of present knowledge}

Each of the foregoing sections has examined in depth one aspect of the science of gastrointestinal physiology and function in relation to probiotics and prebiotics. The following conclusions are derived from the discussions within each section.

\subsection{Intestinal microflora}

The intestinal microflora has been studied using traditional methods. A current problem is the presence of nonculturable species, which require new methodologies to be developed for their detection and measurement.

The establishment of the normal human intestinal microflora, its components and metabolic activities, requires further study. Similarly, knowledge is needed on the composition and activities of the flora in different ethnic groups, at different ages and in different countries.

Prebiotics and a few probiotics have already been shown to have the potential to modify significantly the composition of the intestinal microflora. In particular, the stimulatory effect of fructosyl prebiotics on the growth of bifidobacteria is well established. Moreover, prebiotics and probiotics are interesting tools with which to study the physiological consequences of changes in metabolic activities following such modification.

\subsection{Mucosal function}

There is evidence for a strong interaction between the intestinal microflora, gut mucosa and GALT and the functions and dysfunctions of the gastrointestinal tract. It has been shown that probiotics may change the gut mucosal 
barrier by stabilizing the intestinal mucosa, normalizing intestinal permeability and improving gut immunology. However, there are differences in the function and activity of different probiotics. Another consequence of intake of prebiotics and probiotics is the prevention of overgrowth of pathogenic bacteria and viruses. Taken together, these modifications have been shown to influence the gut barrier system.

Future human studies should consider intestinal immunity and its modulation by resident probiotic bacteria or prebiotic components in more detail. Local release of cytokines induced by inflammatory reactions may amplify adverse reactions to food components within the intestinal tract and other parts of the body.

\subsection{Gastrointestinal physiology}

Gut bacteria play a role in bowel functions like faecal mass, stool frequency, regulation of colonic $\mathrm{pH}$, production of SCFA and salvage of energy from non-digestible food components. Any modification of the microflora is likely to influence these functions, but most of the results of human studies with pro- and prebiotics are preliminary and yet to be confirmed. In particular, the interaction of probiotics and prebiotics with the endocrine activity of the gut requires investigation.

\subsection{Methodology}

There is clearly a need for new methodology to measure and characterize the composition of faecal microflora, in particular in large human nutrition studies.

New biomarkers specifically involved with immune responses need to be defined and validated for nutritional studies. Germ-free animals (gnotobiotic mice) offer a model to clarify the specific effect of a bacterial strain or a food component on a given immune response.

Development of early markers of carcinogenesis is urgently required for human intervention studies.

\subsection{Human studies on health benefits}

9.5.1. Prebiotics (Table 9). There are currently few reports of well-designed and well-documented human

Table 9. Established and postulated functional effects of currently available prebiotics in human subjects

\begin{tabular}{|c|c|}
\hline Established functional effects & $\begin{array}{l}\text { Postulated areas for future } \\
\text { research }\end{array}$ \\
\hline $\begin{array}{l}\text { Non-digestibility and low energy } \\
\text { value }(<9 \mathrm{~kJ} / \mathrm{g})\end{array}$ & $\begin{array}{l}\text { Prevention of intestinal disorders } \\
\text { (IBS, ulcerative colitis) and } \\
\text { infections, including diarrhoea }\end{array}$ \\
\hline $\begin{array}{l}\text { Stool bulking effect } \\
\text { Modulation of the gut flora, } \\
\text { promoting bifidobacteria and } \\
\text { repressing clostridia }\end{array}$ & $\begin{array}{l}\text { Modulation of immune response } \\
\text { Prevention of colon } \\
\text { carcinogenesis } \\
\text { Reduction in serum levels of } \\
\text { triacylglycerols and } \\
\text { cholesterol } \\
\text { Improved bioavailability of } \\
\text { minerals (Ca, Mg) }\end{array}$ \\
\hline
\end{tabular}

IBS, irritable bowel syndrome.
Table 10. Postulated clinical effects of probiotics

\begin{tabular}{ll}
\hline Areas for future research & $\begin{array}{c}\text { Regulation of intestinal motility. } \\
\text { Modulation of intestinal and } \\
\text { systemic immune responses. } \\
\text { Reduction and protection of } \\
\text { radiotherapy-associated intestinal } \\
\text { dysfunction. Prevention of intestinal } \\
\text { cancers } \\
\text { Intestinal microflora effects, } \\
\text { immunomodulation effects, } \\
\text { competitive exclusion, cholesterol } \\
\text { lowering }\end{array}$ \\
\hline
\end{tabular}

intervention studies with prebiotics. Future studies may indicate differences between the effects of prebiotic components. Thus, it is important that each compound is tested separately or in products designed for a particular function.

9.5.2. Probiotics (Table 10). Alleviation of lactose maldigestion symptoms is well characterized for some probiotics. The ability of certain probiotic strains to shorten the duration of rotavirus diarrhoea has been established in several studies. Immunomodulation has been demonstrated for some probiotic strains and one strain has been documented to reduce the recurrence of superficial bladder cancer in human subjects. Novel methodologies are required to provide further data on the mechanisms of competitive exclusion and microflora modification.

For other areas of interest there are still few welldesigned and well-conducted human intervention studies with probiotics. There are indications of significant differences between probiotic bacterial genera and species, and between strains of the same species. Thus, it is important that each strain is tested on its own or in products designed for a particular function. Further research is needed on the immune response, intestinal cancer and the mechanisms that underlie probiotic effects.

9.5.3. Diet and colon cancer. The major challenge at present is to demonstrate within intervention studies which specific dietary factors are able to decrease the risk of colon cancer. Recurrence of large adenomas, the step prior to cancer, is a promising tool for use in human studies and could be applied to prebiotics, probiotics and synbiotics using functional food products as test products. Colon cancer-related variables need to be carefully characterized in the diet and among the microflora.

$$
\text { 9.6. Safety }
$$

The human consumption of prebiotics and probiotics, at least lactic-acid bacteria, appears to be safe.

\section{Recommendations for future research priorities}

Evidence has accumulated to support an important role for gastrointestinal function and the intestinal microflora in maintaining health and preventing diseases. Disturbances of the intestinal microflora may lead to other disturbances and dysfunctions of the gut. Thus, understanding the normal microflora with regard to its metabolic activity and 
influence on the immune and endocrine systems remains a key area for future research.

\subsection{Intestinal microflora}

(1) Develop and validate robust methods that are applicable to large-scale human studies of the intestinal microflora.

(2) Characterize the normal microflora and its activities in healthy persons of all ages.

(3) Identify changes in microflora composition and activity associated with major dysfunctions of the gut.

(4) Identify dietary factors that lead to changes in the microflora and the mechanisms that bring about improvement in health.

\subsection{Short-chain fatty acids and intestinal microflora}

(1) The mechanism by which mixed populations of anaerobic gut bacteria produce different amounts and patterns of SCFA needs to be further investigated.

(2) The role of butyrate in cell differentiation and growth requires further study, particularly of the butyrate response elements in genes and identification of the genes involved.

(3) The role of acetate in metabolism and its regulation, particularly in fasting or starving subjects, requires further study.

(4) In vivo production rates of SCFA and their relation to $\mathrm{H}_{2}$ metabolism and microbial growth need to be determined.

\subsection{Diet and cancer}

(1) Determine the role of the intestinal microflora with respect to composition and activities in carcinogenesis, in particular of the colo-rectum.

(2) Modulation of these aspects by probiotics and prebiotics requires further study.

(3) Novel biomarkers of colorectal carcinogenesis need to be developed and validated.

(4) The influence of diet and the intestinal microflora on DNA damage and repair in normal mucosa requires further study.

\subsection{Immune system}

(1) Improve understanding of GALT function and regulation, and interaction between GALT and the digestive epithelium.

(2) Understand the role of the intestinal microflora and its modification by dietary factors in regulating immune function in health and disease.

(3) Develop and validate biomarkers for immune function and their long-term effects.

\subsection{Gut mucosa}

(1) Develop novel methodologies to study the function and changes in the intestinal mucosa in human subjects.

(2) Characterize the microflora associated with a healthy mucosa and mucus metabolism.
(3) Determine the effects of changes in phase I and phase II mucosal enzymes on xenobiotic metabolism and health.

\section{References}

Adams MR \& Marteau P (1995) On the safety of lactic acid bacteria from food. International Journal of Food Microbiology 27, 262-264.

Aguirre M \& Collins MD (1993) Lactic acid bacteria and human clinical infection. Journal of Applied Bacteriology 75, 95-107.

Alander M, Korpela R, Saxelin M, Vilpponon-Salmila T, MattilaSandholm T \& von Wright A (1996) Recovery of Lactobacillus rhamnosus GG from human colonic biopsies. Letters in Applied Microbiology 24, 361-364.

Ansari B, Coates PJ, Greenstein B \& Hall PA (1993) In situ end labelling (ISEL) detects DNA strand breaks in apoptosis and in other physiological and pathological states. Journal of Pathology 170, $1-8$.

Aso Y \& Akazan H (1992) Prophylactic effect of Lactobacillus casei preparation on the recurrence of superficial bladder cancer. Urology International 49, 125-129.

Aso Y, Akazan H, Kotake T, Tsukamoto T, Imai K \& Naito S (1995) Preventive effect of a Lactobacillus casei preparation on the recurrence of superficial bladder cancer in a double blind trial. European Journal of Urology 27, 104-109.

Awad A, Horvath PJ \& Anderson MS (1991) Influence of butyrate on lipid metabolism, survival, and differentiation of colon cancer cells. Nutrition and Cancer 16, 125-133.

Ballongue J, Schumann C \& Quignon P (1997) Effects of lactulose and lactitol on colonic microflora and enzymatic activity. Scandinavian Journal of Gastroenterology 32, Suppl. 222, 41-44.

Bedenne L, Faivre J, Boutron MC, Piard F, Cauvin JM \& Hillon P (1992) Adenoma-carcinoma sequence or 'de novo' carcinogenesis? A study of adenomatous remnants in a population-based series of large bowel cancers. Cancer 69, 883-888.

Benlounes N, Dupont C, Candahl C, Blaton MA, Desjeux JF \& Heyman M (1996) The threshold for immune cell reactivity to milk antigens decreases in cow's milk allergy with intestinal symptoms. Journal of Allergy and Clinical Immunology 98, $781-789$.

Benno Y, He F, Hosoda M, Hashimoto H, Kojima T, Yamazaki K, Iino H, Mykkänen H \& Salminen S (1996) Effects of Lactobacillus GG yogurt on human intestinal microecology in Japanese subjects. Nutrition Today 31, 9-11.

Biewenga J, van Rees EP \& Sminia T (1993) Induction and regulation of $\operatorname{IgA}$ responses in the microenvironment of the gut. Short analytical review. Clinical Immunology and Immunopathology 67, 1-7.

Binder HJ, Cummings JH \& Soergel KH (editors) (1994) Falk Symposium 73. Short Chain Fatty Acids. Dordrecht, The Netherlands: Kluwer Academic.

Boffa LC, Lupton JR, Mariani MR, Ceppi M, Newmark HL, Scalmati A \& Lipkin M (1992) Modulation of colonic epithelial cell proliferation, histone acetylation, and luminal short chain fatty acids by variation of dietary fiber (wheat bran) in rats. Cancer Research 52, 5906-5912.

Boland CR, Martin MA \& Goldstein IJ (1992) Lectin reactivities as intermediate biomarkers in premalignant colorectal epithelium. Journal of Cellular Biochemistry 16G, 103-109.

Bostick RM, Potter JD, McKenzie DR, Sellers TA, Kushi LH, Steinmetz KA \& Folsom AR (1993) Reduced risk of colon cancer with high intake of vitamin E: the Iowa women's health study. American Journal of Epidemiology 137, 1302-1317.

Boutron MC \& Faivre J (1993) Diet and the adenoma-carcinoma sequence. European Journal of Cancer Prevention 2, 95-98. 
Boutron MC, Faivre J, Marteau P, Couillaut C, Senesse P \& Quipourt V (1996) Calcium, phosphorus, vitamin D, dairy products and colorectal carcinogenesis: a French case-control study. British Journal of Cancer 74, 145-151.

Brandtzaeg P (1995) Molecular and cellular aspects of the secretory immunoglobulin system. Acta Pathologica, Microbiologica et Immunologica Scandinavica 103, 1-19.

Brandtzaeg P, Halstensen TS, Kett K, Krajci P, Kvale D, Rognum TO, Scott H \& Sollid LM (1989) Immunobiology and immunopathology of human gut mucosa: humoral immunity and intraepithelial lymphocytes. Gastroenterology 97, 1562-1584.

Bry L, Falk PG, Midtvedt T \& Gordon J (1996) A model for hostmicrobial interactions in an open mammalian ecosystem. Science 273, 1380-1383.

Bugaut M \& Bentejac M (1993) Biological effects of shortchain fatty acids in nonruminant mammals. Annual Review of Nutrition 13, 217-241.

Burkitt DP (1971) Epidemiology of cancer of the colon and rectum. Cancer 28, 3-13.

Cheng BQ, Trimble RP, Illman RJ, Stone BA \& Topping DL (1987) Comparative effects of dietary wheat bran and its morphological components (aleurone and pericarp seed coat) on volatile fatty acid concentrations in the rat. British Journal of Nutrition 57, 69-76.

Clinton SK (1992) Dietary protein and carcinogenesis. In Nutrition, Toxicity and Cancer, pp.455-479 [IR Rowland, editor]. Boca Raton, FL: CRC Press.

Collins MD \& Gibson GR (1998) Nutritional modulation of microbial ecology. American Journal of Clinical Nutrition (In the Press).

Coussement P (1996) Pre- and synbiotics with inulin and oligofructose. Food Technology in Europe, December 1995/January 1996 issue, $102-104$.

Cummings JH (1993) The effect of dietary fiber on faecal weight and composition. In CRC Handbook of Dietary Fiber in Human Nutrition, pp. 263-349 [GA Spiller, editor]. Boca Raton, FL: CRC Press.

Cummings JH (1994) Non-starch polysaccharides (dietary fibre) including bulk laxatives in constipation. In Constipation, pp. 307-314 [MA Kamm and JE Lennard-Jones, editors]. Petersfield: Wrightson Biomedical Publishing Ltd.

Cummings JH (1995) Short chain fatty acids. In Human Colonic Bacteria: Role in Nutrition, Physiology and Pathology, pp. 101-130 [GR Gibson and GT Macfarlane, editors]. Boca Raton, FL: CRC Press.

Cummings JH (1997) The Large Intestine in Nutrition and Disease. Danone Chair Monograph, pp.1-155. Brussels: Institut Danone.

Cummings JH, Bingham SA, Heaton KW \& Eastwood MA (1992) Faecal weight, colon cancer risk and dietary intake of non-starch polysaccharides (dietary fiber). Gastroenterology 103, 1783-1789.

Cummings JH \& Englyst HN (1987) Fermentation in the large intestine and the available substrates. American Journal of Clinical Nutrition 45, 1243-1255.

Cummings JH, Gibson GR \& Macfarlane GT (1989) Qualitative estimates of fermentation in the hind gut of man. Acta Veterinaria Scandanavica Suppl. 86, 76-82.

Cummings JH, Pomare EW, Branch WJ, Naylor CPE \& Macfarlane GT (1987) Short chain fatty acids in human large intestine, portal, hepatic and venous blood. Gut 28, $1221-1227$

Cummings JH, Roberfroid MB, Andersson H, Barth C, FerroLuzzi A, Ghoos Y, Gibney M, Hermonsen K, James WPT, Korver O, Lairon D, Pascal G \& Voragen AGS (1997) A new look at dietary carbohydrate: chemistry, physiology and health. European Journal of Clinical Nutrition 51, 417-423.
Cummings JH, Rombeau JL \& Sakata T (editors) (1995) Physiological and Clinical Aspects of Short Chain Fatty Acids. Cambridge: Cambridge University Press.

De Simone C, Vesely R, Bianchi Salvadori B \& Jirillo E (1993) The role of probiotics in modulation of the immune system in man and animals. International Journal of Immunotherapy $\mathbf{9}$, 23-28.

Donohue DC \& Salminen S (1996) Safety of probiotic bacteria. Asia Pacific Journal of Clinical Nutrition 5, 25-28.

Duchmann R, Kaiser I, Hermann E, Mayet W, Ewe K \& Meyer zum Büschenfelde KH (1995) Tolerance exists towards resident intestinal flora but is broken in active inflammatory bowel disease (IBD). Clinical and Experimental Immunology 102, $448-455$.

Ducluzeau R (1993) Installation, équilibre et rôle de la flore microbienne du nouveau-né (Development, balance and role of the microbial flora of the newborn). Annales Pédiatriques (Paris) 40, 13-22.

Faivre J, Boutron MC, Hillon P, Bedenne L \& Klepping C (1985) Epidemiology of colorectal cancer. In Diet and Human Carcinogenesis, pp. 123-135 [JV Joosens, MJ Hill and J Geboers, editors]. Amsterdam: Elsevier Scientific Publishers.

Fargeas MJ, Theodorou V, More J, Wal JM, Fioramonti J \& Bueno L (1995) Boosted systemic immune and local responsiveness after intestinal inflammation in orally sensitized guinea pigs. Gastroenterology 109, 53-62.

Frankel WL, Zhang W, Singh A, Klurfeld DM, Don S, Sakata T, Modlin I \& Rombeau JL (1994) Mediation of the trophic effects of short-chain fatty acids on the rat jejunum and colon. Gastroenterology 106, 375-380.

Fuller R (1991) Probiotics in human medicine. Gut 32, 439-442.

Fuller R (editor) (1992) Probiotics. The Scientific Basis. London: Chapman and Hall.

Gaboriau-Routhiau V \& Moreau MC (1996) Gut flora allows recovery of oral tolerance to ovalbumin in mice after transient breakdown mediated by cholera toxin or Escherichia coli heat-labile enterotoxin. Pediatrics Research 39, 625-629.

Gasser F (1994) Safety of lactic acid bacteria and their occurrence in human clinical infections. Bulletin Institut Pasteur 92, 45-67.

Gibson GR, Beatty ER, Wang X \& Cummings JH (1995) Selective stimulation of bifidobacteria in the human colon by oligofructose and inulin. Gastroenterology 108, 975-982.

Gibson GR \& Macfarlane GT (editors) (1995) Human Colonic Bacteria: Role in Nutrition, Physiology and Pathology. Boca Raton, FL: CRC Press.

Gibson GR \& Roberfroid MB (1995) Dietary modulation of the human colonic microbiota: introducing the concept of prebiotics. Journal of Nutrition 125, 1401-1412.

Gibson PR, Moeller I, Kagelari O, Folino M \& Young GP (1992) Contrasting effects of butyrate on the expression of phenotypic markers of differentiation in neoplastic and non-neoplastic colonic epithelial cells in vitro. Journal of Gastroenterology and Hepatology 7, 165-172.

Goldin BR \& Gorbach SL (1984) The effect of milk and lactobacillus feeding on human intestinal bacterial enzyme activity. American Journal of Clinical Nutrition 39, 756-761.

Goldin BR, Gorbach SL, Saxelin M, Barakat S, Gualteri L \& Salminen S (1992) Survival of Lactobacillus species (strain GG) in the human gastrointestinal tract. Digestive Diseases and Sciences 47, 573-575.

Goodlad RA (1989) Gastrointestinal cell proliferation. Digestive Diseases 7, 169-177.

Goodlad RA \& Wright NA (1982) Quantitative studies on epithelial replacement in the gut. Techniques in the Life Sciences P212, 1-23.

Gracey M (1993) Transmission and epidemiology. Bailliere's Clinical Gastroenterology 7, 195-214. 
Greenberg ER, Baron JA, Tosteson TD, Freeman DH Jr, Beck GJ, Bond JH, Colacchio TA, Coller JA, Frankl HD \& Haile RW (1994) A clinical trial of antioxidant vitamins to prevent colorectal adenoma. New England Journal of Medicine 331, 141-147.

Guarino A, Canani RB, Spagnuolo MI, Albano F \& Benedetto LD (1997) Oral bacterial therapy reduces the duration of symptoms and of viral excretion in children with mild diarrhoea. Journal of Pediatric Gastroenterology and Nutrition (In the Press).

Hague A, Manning AM, Hanlon KA, Huschtscha LI, Hart D \& Paraskeva C (1993) Sodium butyrate induces apoptosis in human colonic tumour cell lines in a p53-independent pathway: implications for the possible role of dietary fibre in the prevention of large-bowel cancer. International Journal of Cancer $\mathbf{5 5}$, 498-505.

Hambly RJ, Rumney CJ, Fletcher JME, Rijken P \& Rowland IR (1997) Effects of high and low risk diets on gut-microfloraassociated biomarkers of colon cancer in human-flora-associated rats. Nutrition and Cancer 27, 250-255.

Havenaar R \& Huis in't Veld JHJ (1992) Probiotics; a general view. In The Lactic Acid Bacteria. Vol. 1. The Lactic Acid Bacteria in Health and Disease, pp. 151-170 [BJB Wood, editor]. Barking: Elsevier Applied Science.

Heyman M \& Desjeux JF (1992) Significance of intestinal food protein transport. Journal of Pediatric Gastroenterology and Nutrition 15, 48-57.

Heyman M, Ducroc R, Desjeux JF \& Morgat JL (1982) Horseradish peroxidase transport across adult rabbit jejunum in vitro. American Journal of Physiology 242, G558-G564.

Heyman M, Gorthier G, Petit A, Meslin J-C, Moreau C \& Desjeux J-F (1987) Intestinal absorption of macromolecules during viral enteritis: an experimental study on rotavirusinfected conventional and germ-free mice. Pediatrics Research 22, 72-78.

Hosoda M, Ile F, Hiramaru M, Hashimoto H \& Benno Y (1994) Effects of Lactobacillus GG intake on faecal microflora and defacation in healthy volunteers. Bifidus 8, 21-28.

Howe G, Benito E, Casteleto R, Cornée J, Estève J, Gallagher RP, Iscovich JM, Deng-ao J, Kaaks R, Kune GA, Kune S, L'Abbé KA, Lee HP, Miller AB, Peters RK, Potter JD, Riboli E, Slattery ML, Trichopoulos D, Tuyns A, Tzonou A, Whittemore AS, Wu-Williams AH \& Zeng S (1992) Dietary intake of fiber and decreased risk of cancers of the colon and rectum: evidence from the combined analysis of 13 case-control studies. Journal of the National Cancer Institute 84, 1887-1896.

Isolauri E (1995) The treatment of cow's milk allergy. European Journal of Clinical Nutrition 49, 549-555.

Isolauri E, Kaila M, Arvola T, Majamaa H, Rantala I, Virtanen E \& Arvilommi H (1993a) Diet during rotavirus enteritis affects jejunal permeability to macromolecules in suckling rats. Pediatrics Research 33, 548-553.

Isolauri E, Majamaa $\mathrm{H}$, Arvola $\mathrm{T}$, Rantala I, Virtanen $\mathrm{F}$ \& Arvilommi H (1993b) Lactobacillus casei strain GG reverses increased intestinal permeability induced by cow milk in suckling rats. Gastroenterology 105, 1643-1650.

Ito M, Kimura M, Deguchi Y, Miyamori-Watabe A, Yajima T \& Kan T (1993) Effects of transgalactosylated disaccharides on the human intestinal microflora and their metabolism. Journal of Nutritional Science and Vitaminology 39, 279-288.

Jalonen $\mathrm{T}$, Isolauri $\mathrm{E}$, Heyman $\mathbf{M}$, Crain-Denoyelle A-M, Sillanaukee P \& Koivula T (1991) Increased $\beta$-lactoglobulin absorption during rotavirus enteritis in infants: relationship to sugar permeability. Pediatrics Research 30, 290-293.

Kaila M, Isolauri E, Soppi E, Virtanen V, Laine S \& Arvilommi H (1992) Enhancement of the circulating antibody secreting cell response in human diarrhea by a human Lactobacillus strain. Pediatrics Research 32, 141-144.
Kim YS, Gum JR, Ho SB \& Deng G (1994) Colonocyte differentiation and proliferation: overview and the butyrateinduced transcriptional regulation of oncodevelopmental placental-like alkaline phosphatase gene in colon cancer cells. In Falk Symposium 73. Short Chain Fatty Acids, pp. 119-134 [HJ Binder, JH Cummings and KH Soergel, editors]. Lancaster: Kluwer Academic Publishers.

Kim YS, Tsao D, Siddiqui B, Whitehead JS, Arnstein P, Bennett J \& Hicks J (1980) Effects of sodium butyrate and dimethylsulfoxide on biochemical properties of human colon cancer cells. Cancer 45, 1185-1192.

Kok RG, De Waal A, Schut F, Welling GW, Weenk G \& Hellingwerf KJ (1996) Specific detection and analysis of a probiotic Bifidobacterium strain in infant faeces. Applied Environmental Microbiology 62, 3668-3672.

Kolars JC, Levitt MD, Aouiji M \& Savaiano DA (1984) Yogurt an autodigesting source of lactose. New England Journal of Medicine 310, $1-3$.

Langendijk PS, Schut F, Jansen GJ, Raangs GC, Kamphuis GR, Wilkinson MHF \& Welling GW (1995) Quantitative fluorescence in situ hybridization of Bifidobacterium spp. with genus-specific 16S rRNA-targeted probes and its application in faecal samples. Applied Environmental Microbiology 61, 3069-3075.

Lee YK \& Salminen S (1995) The coming of age of probiotics. Trends in Food Science Technology 6, 241-245.

Lifschitz CH, Carrazza FR, Feste AS \& Klein PD (1995) In vivo study of colonic fermentation of carbohydrate in infants. Journal of Paediatric Gastroenterology and Nutrition 20, 59-64.

Ling WH, Korpela R, Mykkänen H \& Salminen S (1994) Lactobacillus strain GG and fiber supplementation decreases colonic hydrolytic and reductive enzyme activities in healthy female subjects. Journal of Nutrition 121, 18-23.

Lipkin M (1988) Biomarkers of increased susceptibility to gastrointestinal cancer: new application to studies of cancer prevention in human subjects. Cancer Research 43, 1899-1904.

Livesey G (1990) Energy values of unavailable carbohydrates and diets: an inquiry and analysis. American Journal of Clinical Nutrition 51, 617-637.

McCartney AL, Wenzhi W \& Tannock GT (1996) Molecular analysis of the composition of the bifidobacterial and lactobacillus microflora of humans. Applied Environmental Microbiology 62, 4608-4613.

MacDonald TT (1993) Aetiology of Crohn's disease. Archives of Disease in Childhood 68, 623-625.

Macfarlane GT, Gibson GR, Drasar BS \& Cummings JH (1995) Metabolic significance of the gut microflora. In Gastrointestinal and Oesophageal Pathology, 2nd ed., pp. 249-274 [R Whitehead, editor]. Edinburgh: Churchill Livingstone.

Macfarlane GT \& Macfarlane S (1995) Proteolysis and amino acid fermentation. In Human Colonic Bacteria: Role in Nutrition, Physiology, and Pathology, pp.75-100 [GR Gibson and GT Macfarlane, editors]. London: CRC Press.

McIntyre A, Gibson PR \& Young GP (1993) Butyrate production from dietary fibre and protection against large bowel cancer in a rat model. Gut 34, 386-391.

McIntyre A, Young GP, Taranto T, Gibson PR \& Ward PB (1991) Different fibres have different regional effects on luminal contents of rat colon. Gastroenterology 101, 1274-1281.

McKay DM \& Perdue MH (1993) Intestinal epithelial function: the case for immunophysiological regulation. Cells and mediators (First of two parts). Digestive Diseases and Sciences 38, 1377-1387.

MacLennan R, Macrae F, Bain C, Battistutta D, Chapuis P, Gratten H, Lambert J, Newland RC, Ngu M \& Russell A (1995) Randomized trial of intake of fat, fiber, and beta carotene to prevent colorectal adenomas. Journal of the National Cancer Institute 87, 1760-1766. 
Marteau P, Flourié B, Pochart P, Chastang C, Desjeux JF \& Rambaud JC (1990) Role of the microbial lactase (EC 3.2.1.23) activity from yoghurt on the intestinal absorption of lactose: an in vivo study in lactase-deficient humans. British Journal of Nutrition 64, 71-79.

Marteau P, Minekus M, Havenaar R \& Huis in't Veld JHJ (1997a) Survival of lactic acid bacteria in a dynamic model of the stomach and small intestine: validation and the effects of bile. Journal of Dairy Science 80, 1031-1037.

Marteau P \& Rambaud JC (1993) Potential for using lactic acid bacteria for therapy and immunomodulation in man. FEMS Microbiology Review 12, 207-220.

Marteau P, Vaerman JP, Dehennin JP, Bord S, Brassart D, Pochart P, Desjeux JF \& Rambaud JC (1997b) Effects of intrajejunal perfusion and chronic ingestion of Lactobacillus johnsonii strain Lal on serum concentrations and jejunal secretions of immunoglobulins and serum proteins in healthy humans. Gastroenterology and Clinical Biology 21, 293-298.

Martin MS, Justrabo E, Jeannin JF, Leclerc A \& Martin F (1981) Effect of dietary chenodeoxycholic acid on intestinal carcinogenesis induced by 1,2 dimethylhydrazine in mice and hamsters. British Journal of Cancer 43, 884-886.

Maskens AP (1976) Histogenesis and growth pattern of 1,2dimethylhydrazine-induced rat colon adenocarcinoma. Cancer Research 36, 1585-1592.

Maskens AP \& Dujardin Loits RM (1981) Experimental adenomas and carcinomas of the large intestine behave as distinct entities. Cancer 47, 81-89.

Molis C, Flourié B, Ouarne F, Gailing MF, Lartigue S, Guibert A, Bornet F \& Galmiche JP (1996) Digestion, excretion and energy value of fructo oligosaccharides in healthy humans. American Journal of Clinical Nutrition 64, 324-328.

Moreau MC, Bisetti N \& Dubuquoy C (1998) Immunomodulating properties of a strain of Bifidobacterium used as probiotic on the faecal and cellular intestinal $\operatorname{IgA}$ anti-rotavirus responses in mice. In Functional Foods Proceedings. Royal Society of Chemistry.

Moreau MC \& Coste M (1993) Immune responses to dietary protein antigens. World Review of Nutrition and Dietetics $\mathbf{7 4}$, $22-57$

Moreau MC \& Gaboriau-Routhiau V (1996) The absence of gut flora, the doses of antigen ingested and aging affect the longterm peripheral tolerance induced by ovalbumin feeding in mice. Research Immunology 147, 49-59. .

Moreau MC, Nuyts V \& Raibaud P (1994) Effet de l'ingestion d'un lait fermenté avec Lactobacillus bulgaricus et Streptococcus thermophilus sur la stimulation de l'immunité de l'hôte: étude chez la souris axénique (Effect of the ingestion of a fermented milk on the stimulation of immunity in germ-free mice). Cahiers Decarboxylation Nutrition et Diététique 29, 341-347.

Morotomi M (1996) Properties of Lactobacillus casei Shirota strain as probiotics. Asia Pacific Journal of Clinical Nutrition 5, 29-30.

Mosmann T (1983) Rapid colorimetric assay for cellular growth and survival: application to proliferative and cytotoxic assays. Journal of Immunology Methods 65, 55-63.

Muyzer G, de Waal EC \& Uitterlinden AG (1993) Profiling complex microbial populations by denaturing gradient gel electrophoresis analysis of polymerase chain reaction-amplified genes coding for 16S rRNA. Applied Environmental Microbiology 59, 695-700.

Pace N (1996) New perspective on the natural microbial world: molecular microbial ecology. ASM News 62, 463-470

Pant AR, Graham SM, Allen SJ, Harikul S, Sabohaeron A, Cuevas L \& Hart CA (1996) Lactobacillus GG and acute diarrhoea in young children in the tropics. Journal of Tropical Pediatrics $\mathbf{4 2}$, $162-165$.
Perdigon G, Alvarez S, Rachid M, Agüero G \& Gobatto N (1996) Probiotic bacteria for humans: clinical systems for evaluation of effectiveness. Journal of Dairy Science 78, 1597-1606.

Pitcher MCL \& Cummings JH (1995) Colonic fermentation, sulphur metabolism and ulcerative colitis. In Falk Symposium 85. Inflammatory Bowel Disease, pp.529-543 [GNJ Tytgat, JFWM Bartelsman and SHJ van Deventer, editors]. London: Kluwer Academic Publishers.

Pitcher MCL \& Cummings JH (1996) Hydrogen sulphide: a bacterial toxin in ulcerative colitis? Gut 39, 1-4.

Podolsky DK (1991) Inflammatory bowel disease. (First of two parts.) New England Journal of Medicine 325, 928-937.

Pomare EW, Branch WJ \& Cummings JH (1985) Carbohydrate fermentation in the human colon and its relation to acetate concentration in venous blood. Journal of Clinical Investigation 75, 1448-1454.

Potter JD, Slattery ML, Bostock RM \& Gapstur SM (1993) Colon cancer: a review of the epidemiology. Epidemiology Review 15, 499-545.

Rafter JJ, Child P, Anderson AM, Alder R, Eng V \& Bruce WR (1987) Cellular toxicity of faecal water depends on diet. American Journal of Clinical Nutrition 45, 559-563.

Raza S, Graham SM, Allen SJ, Sultana S, Cuevas L \& Hart CA (1995) Lactobacillus GG promotes recovery from acute nonbloody diarrhoea in Pakistan. Pediatric Infection and Disease 14, 107-111.

Risio M (1992) Cell proliferation in colorectal tumour progression: an immunohistochemical approach to intermediate biomarkers. Journal of Cellular Biochemistry 16G, 79-87.

Ritchie JK, Wadsworth J, Lennard-Jones JE \& Rogers E (1987) Controlled multicentre therapeutic trial of an unrefined carbohydrate, fibre-rich diet in Crohn's disease. British Medical Journal 295, 517-520.

Roberfroid MB (1996) Functional effects of food components and the gastrointestinal system: chicory fructooligosaccharides. Nutrition Reviews 54, S38-S42.

Roberfroid MB, Bornet F, Bouley C \& Cummings JH (1995) Colonic microflora: nutrition and health. Nutrition Reviews 53, $127-130$.

Roberfroid M, Gibson GR \& Delzenne N (1993) The biochemistry of oligofructose, a non-digestible fiber: an approach to calculate its caloric value. Nutrition Reviews 51, 137-146.

Roberfroid MB, Van Loo JAE \& Gibson GR (1997) The bifidogenic nature of chicory inulin and its hydrolysis products. Journal of Nutrition (In the Press).

Roediger WEW, Duncan A, Kapaniris O \& Millard S (1993) Reducing sulfur compounds of the colon impair colonocyte nutrition: implications for ulcerative colitis. Gastroenterology 104, 802-809.

Roland N, Nugon-Baudon L, Andrieux C \& Szylit O (1995) Comparative study of the fermentative characteristics of inulin and different types of fibre in rats inoculated with a human whole faecal flora. British Journal of Nutrition 74, 239-249.

Roncucci L (1992) Early events in human colorectal carcinogenesis. Aberrant crypts and microadenoma. Italian Journal of Gastroenterology 24, 498-501.

Rowland I (1991) Nutrition and gut flora metabolism. In Nutrition, Toxicity and Cancer, pp. 113-135 [IR Rowland, editor]. Boca Raton, FL: CRC Press.

Rowland IR (1995) Toxicology of the colon: role of the intestinal microflora. In Human Colonic Bacteria: Role in Nutrition, Physiology and Pathology, pp. 155-174 [GR Gibson and GT Macfarlane, editors]. London: CRC Press.

Saavedra JM, Bauman NA, Oung I, Perman JA \& Yolken RH (1994) Feeding of Bifidobacterium bifidum and Streptococcus thermophilus to infants in hospital for prevention 
of diarrhoea and shedding of rotavirus. Lancet 344, 10461049.

Sakamoto J, Shigeyuki N, Sugawara K, Iwane S \& Munakata A (1996) Comparison of resistant starch with cellulose diet on 1,2-dimethylhydrazine-induced colonic carcinogenesis in rats. Gastroenterology 110, 116-120.

Sakata T (1987) Stimulatory effect of short chain fatty acids on epithelial cell proliferation in the rat intestine: a possible explanation for trophic effects of fermentable fibre, gut microbes and luminal trophic factors. British Journal of Nutrition 58, 95-103.

Salminen S, Isolauri E \& Salminen E (1996a) Clinical uses of probiotics for stabilizing the gut mucosal barrier: successful strains and future challenges. Anton. Leeuwenhoek 70, 347-358.

Salminen S, Isolauri E \& Salminen E (1996b) Probiotics and stabilisation of the gut mucosal barrier. Asia Pacific Journal of Clinical Nutrition 5, 53-56.

Salminen S, Laine M, von Wright A, Vuopio-Varkila J, Korhonen T \& Mattila-Sandholm T (1996c) Development of selection criteria for probiotic strains to assess their potential in functional foods: a Nordic and European approach. Bioscience Microflora $15,61-67$.

Sanders ME (1993) Summary of the conclusions from a consensus panel of experts on health attributes on lactic cultures: significance to fluid milk products containing cultures. Journal of Dairy Science 76, 1819-1828.

Sanderson IR \& Walker WA (1993) Uptake and transport of macromolecules by the intestine: possible role in clinical disorders (an update). Gastroenterology 104, 622-639.

Savarino SJ \& Bourgeois AL (1993) Diarrhoeal disease: current concepts and future challenges. Epidemiology of diarrhoeal diseases in developed countries. Transcript of the Royal Society of Tropical Medicine and Hygiene 87, 7-11.

Saxelin M, Chuang NH, Chassy B, Rautelin H, Mäkelä PH, Salminen S \& Gorbach SL (1996a) Lactobacilli and bacteremia in Southern Finland, 1989-1992. Clinical Infection and Disease 22, 564-566.

Saxelin M, Rautelin H, Salminen S \& Mäkelä P (1996b) The safety of commercial products with viable Lactobacillus strains. Infection and Disease in Clinical Practice 5, 331-335.

Schiffrin E, Rochat F, Link-Amster H, Aeschlimann J \& DonnetHugues A (1995) Immunomodulation of blood cells following the ingestion of lactic acid bacteria. Journal of Dairy Science 78, 491-497.

Shornikova AV, Casas I, Isolauri E, Mykkänen H \& Vesikari T (1997) Lactobacillus reuteri as a therapeutic agent in acute diarrhea in young children. Journal of Pediatric Gastroenterology and Nutrition 24, 399-404.

Solis-Pereyra B \& Lemonnier D (1996) Induction of human cytokines by bacteria used in dairy foods. Nutrition Research 13, $1127-1140$

Staatscourant (1996) Toelating nieuw voedingsmiddel. Galactooligosaccharides (Acceptance of New Nutrient. Galactooligosaccharides) no. 91, p. 7.

Stephen A (1994) Propionate - sources and effect on lipid metabolism. In Falk Symposium 73. Short Chain Fatty Acids, pp. 260-271 [HJ Binder, JH Cummings and KH Soergel, editors]. Dordrecht, The Netherlands: Kluwer Academic Publishers.

Sütas Y, Hurme M \& Isolauri E (1996a) Downregulation of antiCD3 antibody-induced IL-4 production by bovine caseins hydrolysed with Lactobacillus GG-derived enzymes. Scandinavian Journal of Immunology 43, 687-689.

Sütas Y, Soppi E, Korhonen H, Syväoja EL, Saxelin M, Rokka T \& Isolauri E (1996b) Suppression of lymphocyte proliferation in vitro by bovine caseins hydrolysed with Lactobacillus GGderived enzymes. Journal of Allergy and Clinical Immunology 98, 216-224.

Szarka CE, Pfeiffer GR \& Hum ST (1995) Glutathione-Stransferase activity and glutathione S-transferase $\mu$ expression in subjects with risk for colorectal cancer. Cancer Research $\mathbf{5 5}$, 2789-2793.

Terada A, Hara H, Kataoka M \& Mitsuoka T (1992) Effect of lactulose on the composition and metabolic activity of the human faecal flora. Microbial Ecology in Health and Disease 5, 43-50.

Thompson WG \& Gomborone JE (1993) Irritable bowel syndrome: pathogenesis and management. Lancet 341, 1569-1572.

Thompson WG \& Heaton KW (1980) Functional bowel disorders in apparently healthy people. American Gastroenterology Association 79, 283-288.

Todesco T, Rao VA, Bosello O \& Jenkins DJA (1991) Propionate lowers blood glucose and alters lipid metabolism in healthy subjects. American Journal of Clinical Nutrition 54, $860-865$.

Trock B, Lanza E \& Greenwald P (1990) Dietary fiber, vegetables, and colon cancer: critical review and meta-analyses of the epidemiologic evidence. Journal of the National Cancer Institute 82, 650-661.

Tytgat GNJ, Bartelsman JFWM \& van Deventer SJH (editors) (1995) Falk Symposium 85. Inflammatory Bowel Diseases. London: Kluwer Academic Publishers.

Umesaki Y (1989) Intestinal glycolipids and their role in intestinal colonization of mice. Bifidobacteria Microflora $\mathbf{8}$, 13-22.

Umesaki Y, Okada Y, Imaoka A, Setoyama H \& Matsumoto S (1997) Interactions between epithelial cells and bacteria, normal and pathogenic. Science 276, 964-965.

Umesaki Y, Okada Y, Matsumoto S, Imaoka A \& Setoyama H (1995) Segmented filamentous bacteria are indigenous intestinal bacteria that activate intraepithelial lymphocytes and induce MHC class II molecules and fucosyl asialoGM1 glycolipids on the small intestinal epithelial cells in ex-germ-free mouse. Microbial Immunology 39, 555-562.

Van Loo J, Coussement P, De Leenheer L, Hoebregs H \& Smits G (1995) On the presence of inulin and oligofructose as natural ingredients in the Western diet. Critical Reviews in Food Science and Nutrition 35, 525-552.

van Munster IP, Tangerman A \& Nagengast FM (1994) Effect of resistant starch on colonic fermentation, bile acid metabolism, and mucosal proliferation. Digestive Diseases and Sciences 39 , 834-842.

Venter CS, Vorster HH \& Cummings JH (1989) Effects of dietary propionate on carbohydrate and lipid metabolism in man. American Journal of Gastroenterology 85, 549-553.

Venturi M, Hambly RJ, Glinghammar B, Rafter JJ \& Rowland IR (1997) Genotoxic activity in human faecal water and the role of bile acids: a study using the Comet assay. Carcinogenesis (In the Press)

Wasan HS \& Goodlad RA (1996) Fibre-supplemented foods may damage your health. Lancet 348, 319-320.

Wattenberg LW (1983) Inhibition of neoplasia by minor dietary constituents. Cancer Research 43, Suppl., 2448s-2453s.

Weiner HL, Friedman A, Miller A, Khoury SJ, Al-Sabbagh A, Santos L, Sayegh M, Nussenblatt RB, Trentham DE \& Hafler DA (1994) Oral tolerance: immunologic mechanisms and treatment of animal and human organ-specific autoimmune diseases by oral administration of autoantigens. Annual Review of Immunology 12, 809-837.

Weisburger J (1973) Chemical carcinogens and their mode of action in colonic neoplasia. Disease of the Colon and Rectum 289, 1099-1103. 
Whitehead RH, Young GP \& Bathal PS (1986) Effects of short chain fatty acids on a new human colon carcinoma cell line (LIM 1215). Gut 27, 1457-1463.

Wilson KH \& Blitchington RB (1996) Human colonic biota studied by ribosomal DNA sequence analysis. Applied Environmental Microbiology 62, 2273-2278.
Wright NA \& Alison M (1984) The Biology of Epithelial Cell Populations. Oxford: Oxford University Press.

Young GP, McIntyre A, Albert V, Folino M, Muir JG \& Gibson PR (1996) Wheat bran suppresses potato-starch potentiated colorectal tumorigenesis at the aberrant crypt stage in a rat model. Gastroenterology 110, 508-514. 